\title{
KASZÁS GÁBOR
}

„PLEINAIR ERFUNDEN ...”

ADALÉKOK CSONTVÁRY PLEIN AIR-TANULMÁNYAIHOZ (1897-1903)

A Csontváry-képek születésének pontos körülményei és a festő munkamódszere körül ma még számtalan részlet, körülmény feltárásra vár. Hogyan és hol készültek a festő hatalmas vásznai? Valóban ennyit utazott Csontváry? Esetleg fotókat használt a munka során? S ha használt, a végleges mü létrejöttében mekkora szerepük volt ezeknek a felvételeknek ${ }^{2}$ A megválaszolatlan kérdések egyik alapvető oka abban rejlik, hogy a kutatás Csontváry képi világának értelmezését vagy a mitikus elemekkel tarkított életpálya felől közelítette meg, vagy a 19. századi festészeti tradíció kontextusába kívánta beágyazni. Ha e két szempont valamelyike felől közelítünk Csontváry festészetéhez, több érdekes részlet, információ fölött elsiklunk. Ezekből az aspektusokból sokszor fel sem tünik az alkotói módszer precíz átgondoltsága, a következetesen felépített képi logika: pontosan azok a részletek, melyek speciálisan a festészet müfajának belső törvényszerüségeiből adódnak. Úgy gondolom, épp ezért szükséges kísérletet tenni Csontváry alkotói gyakorlatának feltérképezésére. Hagynunk kell, hogy képei önmaguk tárják fel viszonyukat a valósághoz, s így közelebb juthatunk munkamódszeréhez, festészeti gyakorlatához, müvészi elképzeléseihez is.

Csontváry alkotói gyakorlatának talán legcélravezetőbb feltárását a modellként szolgáló táj és a megfestett kép közötti viszony alapos vizsgálatával végezhetjük el. A feladathoz az 1897. év és $A$ taorminai görög színház romjai (1904-1905) címü alkotás elkészülte közötti időszak tájábrázolásait veszem alapul. ${ }^{3}$ Célom, hogy a vizsgált helyszínek és képek viszonyából feltárjam a festő munkamódszerének logikáját. Ezt követően pedig összefüggéseket keressek Csontváry tájfestészete és müvészeti elkép- zelései között, illetve megpróbáljak néhány olyan gyakorlati vonatkozású kérdésre is választ találni, melyek idáig tisztázatlanok voltak az életmüben.

Már Csontváry címadásaiból is sejthető, hogy az 1899 és 1905 között készült tájképek többségét fénytanulmányoknak tekintette a múvész. ${ }^{4}$ Láthatóan nagy körültekintéssel választott címeket, melyekben az uralkodó fényviszonyok pontos napszakát sem mulasztotta el megadni. A világító éj, visszatekintő nap, holdtölte, naplemente, holdvilágos jelzőket nemcsak a magyar, de kisebb-nagyobb változtatásokkal német és francia nyelvü katalógusaiban is rendre szerepeltette. A plein air-tanulmányok stúdiumjellegét erősíti az a tény is, hogy a főmüvek elkészültével már maga a festő megkezdte ezeknek a képeknek a hátrasorolását az életmüben. Az 1908-as budapesti és az 1910-es berlini katalógusok fontossági sorrendbe szerkesztett mütárgylistáin egyaránt a „középmezőnybe” helyezte e festményeket. ${ }^{5}$ Sőt, az a körülmény sem hanyagolható el, hogy a vizsgált alkotások kivétel nélkül családtagoktól, illetve a gácsi patikából kerültek elő. Tehát egyik sem tartozott a festő budapesti mütermében őrzött legféltettebb darabok közé. ${ }^{6}$

A szó hagyományos értelmében azonban mégsem tekinthetők ezek a képek stúdiumoknak. Egyik sem szokványos fényanalízis, mert - bár mindegyikhez egy-egy napszakot rendel a festő - rajtuk nem a plein airre jellemző, pillanatnyiságot tükröző fényviszonyok elevenednek meg. Mi sem bizonyítja ezt jobban, mint hogy a festő œuvre-jegyzékeinek összeállítói számára eddig éppen a napszakok pontos azonosítása okozta a legnagyobb fejtörést. ${ }^{7}$ A fényviszonyok sajátos alkalmazása arra enged következtetni, hogy Csontváry plein air-képei túl- 
mutatnak a kor realista-naturalista festészeti gyakorlatán. E technika pontos részleteiről eddig nem volt elég ismeretünk. A modell és a megfestett táj viszonyrendszerét vizsgálva azonban több múvészi "fogást” fedezhetünk fel, sőt, konzekvenciákat is levonhatunk. Például arra vonatkozólag, hogy mit jelent Csontváry számára a sajátosan értelmezett plein air-gyakorlat, hogy mik azok a "távlatok", amelyek megnyílnak vásznain, hogy mit jelent az idő szublimálása a képein, s mik annak a szimultaneitásnak a komponensei, amelyek által kozmológiája érvényre jut tájfestészetében.

\section{I.}

\section{CSONTVÁRY KÉPPÁRJAI}

Csontváry 1895 és 1905 között készült tájképeinek vizsgált helyszíneit látva leszögezhető: a festő mind topografikus értelemben, mind a fényviszonyokat tekintve a tájat pontosan követte vásznain. Túlzás nélkül állítható, hogy plein air-képeinek megfestésekor minden pontosan ott és akkor látható, amiképp azt a mester láttatja. Igaz ugyan, hogy a valóságban elénk táruló látványt bizonyos mértékig torzítja - feszíti a kompozíciót, fokozza a kép összhatását -, ezek a módosítások azonban minden esetben a képépítésre vezethetők vissza. A homlokzatokat, épületrészleteket, tájrajzi elemek részleteit, és ami a legmeglepőbb, a fényviszonyokat sem módosítja.
Ma is pontosan meghatározhatók azok a pontok, ahonnét képeit festette. Nem mérlegelt, nem kompilált. Mindent akkurátus részletességgel rögzített. Az akkurátus munka nyomaira bukkanhatunk még ott is, ahol a korábbi kutatás a festő „,szakmai" hiányosságait vagy épp fantáziájának "túlcsordulását" vélte felfedezni. Ilyen például $A$ taorminai görög színház romjai (1904-1905) című kép jobb oldali árkádjában látható liget, ami valóban szürreálisnak, kivágatszerűnek hat a „nagytávlatú" képen. ${ }^{8} \mathrm{Az}$ árkád alatt látható részletek azonban topográfiailag helyesek. Az ívben a színház alatt fekvő közkertet, a ma már jóval terebélyesebb növényzettel bíró giardino Villa Comunalét és a mögötte 250 méter mélységben húzódó partszakasz párás atmoszféráját láttatja a festő. ${ }^{9}$

E meglepő alapossággal és részletességgel készült festményeket két szempont alapján igyekszem az adott táj valós fizikai látványával összevetni. Egyrészt a térre, másrészt az időre vonatkozó megfigyelésekkel kívánom a „modell” és a kép viszonyát feltárni (1-2. kép).

\section{A tér}

Csontváry már festői praxisa kezdetén kísérletezett a kor szokványos térábrázolási sémáinak meghaladásával. „.... szerkesztési módjában pedig viszszanyúlt a mértanilag korrekt perspektíva előtti

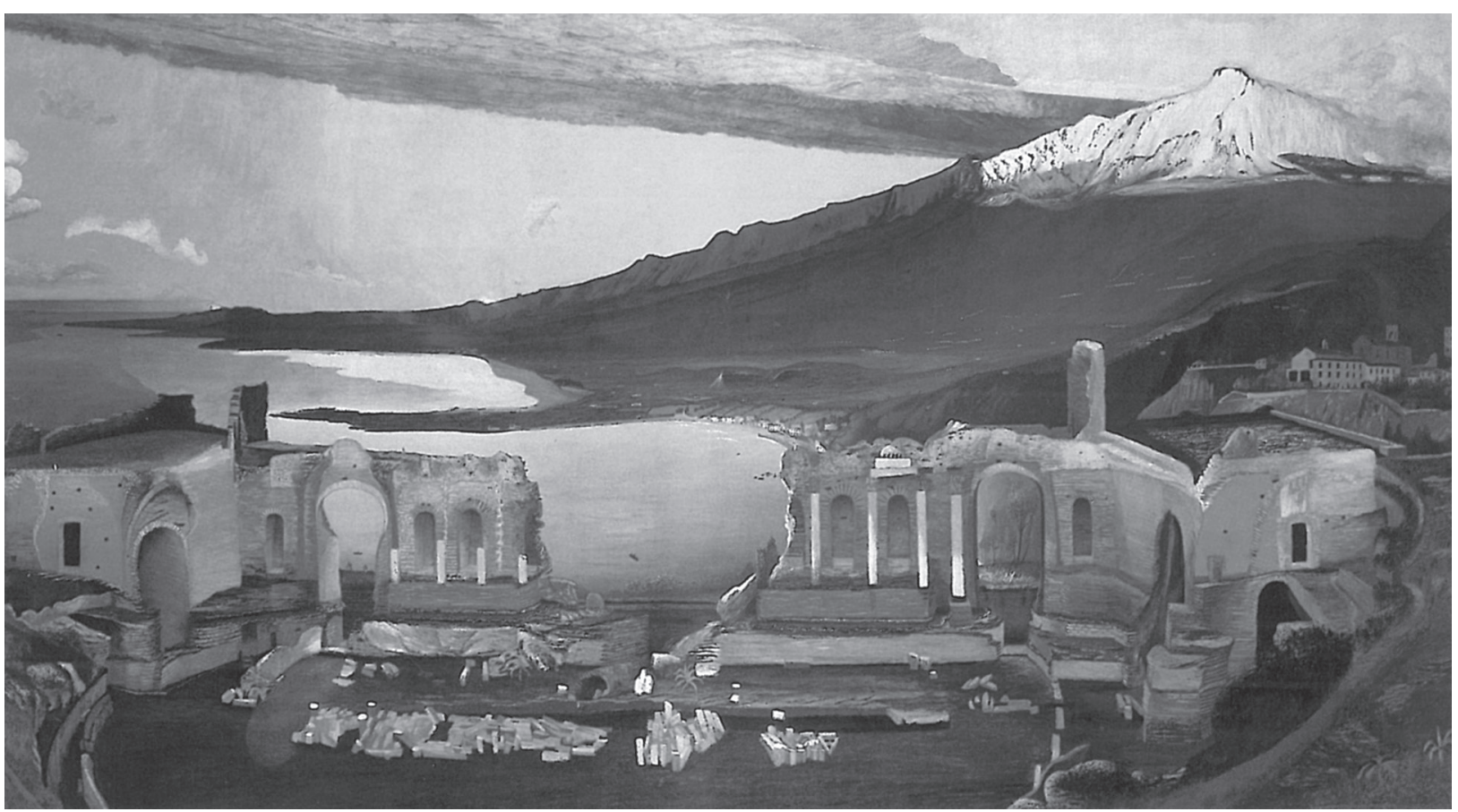

1. Csontváry Kosztka Tivadar: A taorminai görög színház romjai, 1904-1905. Budapest, Magyar Nemzeti Galéria, ltsz.: 93.32 T 


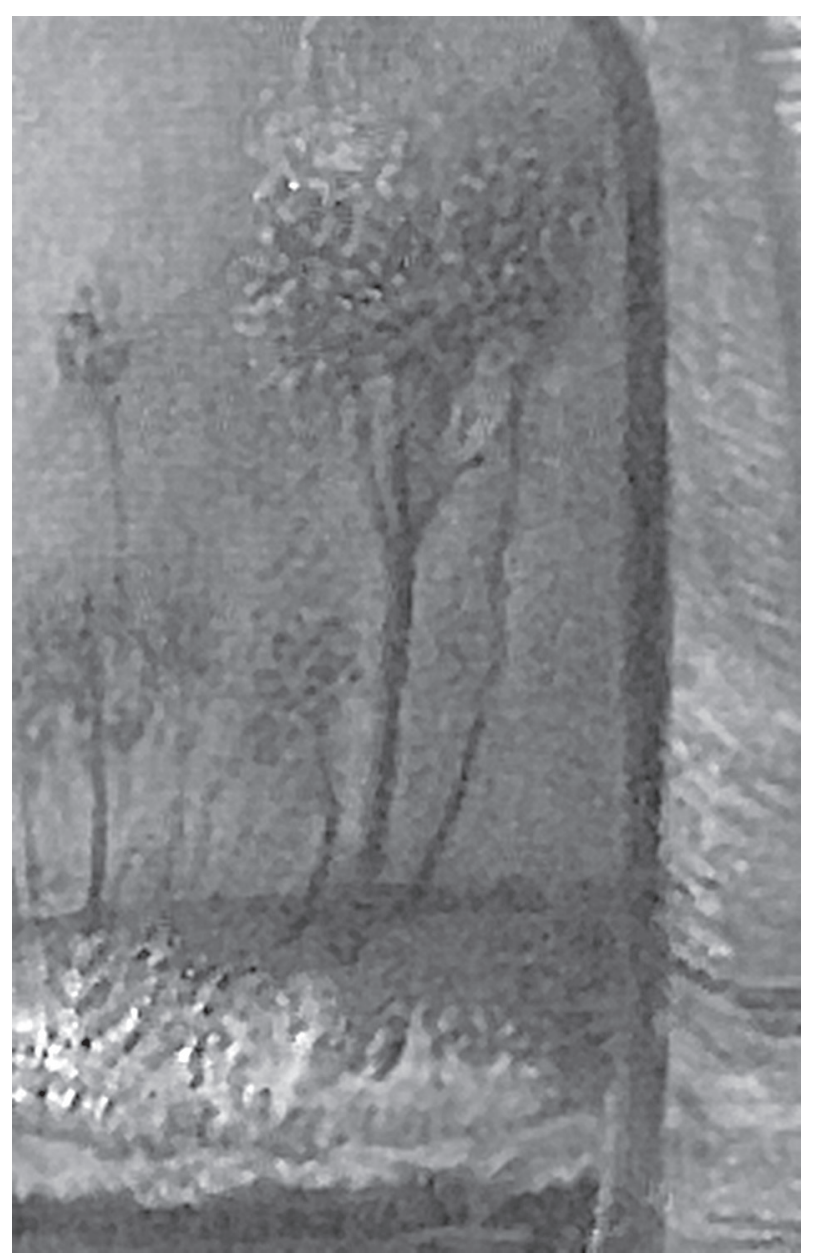

2. Részlet A taorminai görög színház romjai (1904-1905) címü festményröl

tapasztalati, szubjektíve motivált téralakításhoz, feladta az egy nézőpont szigorát, azaz a szabatos szerkesztés kulcspontját... Szerkesztésének lényege volt, hogy poetikusan keverte az axonometrikus és naiv perspektivikus megoldásokat... szimbolikus teret kapcsolt össze egy kvázi valóságos térszerkezettel" - írja Csontváry térképzéséről Németh Lajos. ${ }^{10}$

Mezei Ottó mutatott rá, hogy az Almát hámozó öregasszonyon (1894) olyan sajátos térszerkesztést alkalmaz a festö, amely abszolút szokatlan volt a maga korában (3. kép). A különleges konkáv gömbfelületre emlékeztető képsík tanulmányozása során Mezei egy egészen modern látványszerkesztési eljárás, a gömbperspektíva technikáját hozza fel párhuzamként. „A gömbperspektíva az egyetlen megszerkeszthető távlati ábrázolási mód, amely az adott térbeli jelenséget teljességében és megszakítatlan folyamatosságában 180-fokos körbefordulással, síkba kiterítve képes szemléltetni."11

Csontváry a figura kivágatként történő láttatása helyett az almát hámozó térbeli alakját gömbszerűen meghajlított látványban igyekszik rögzíteni a

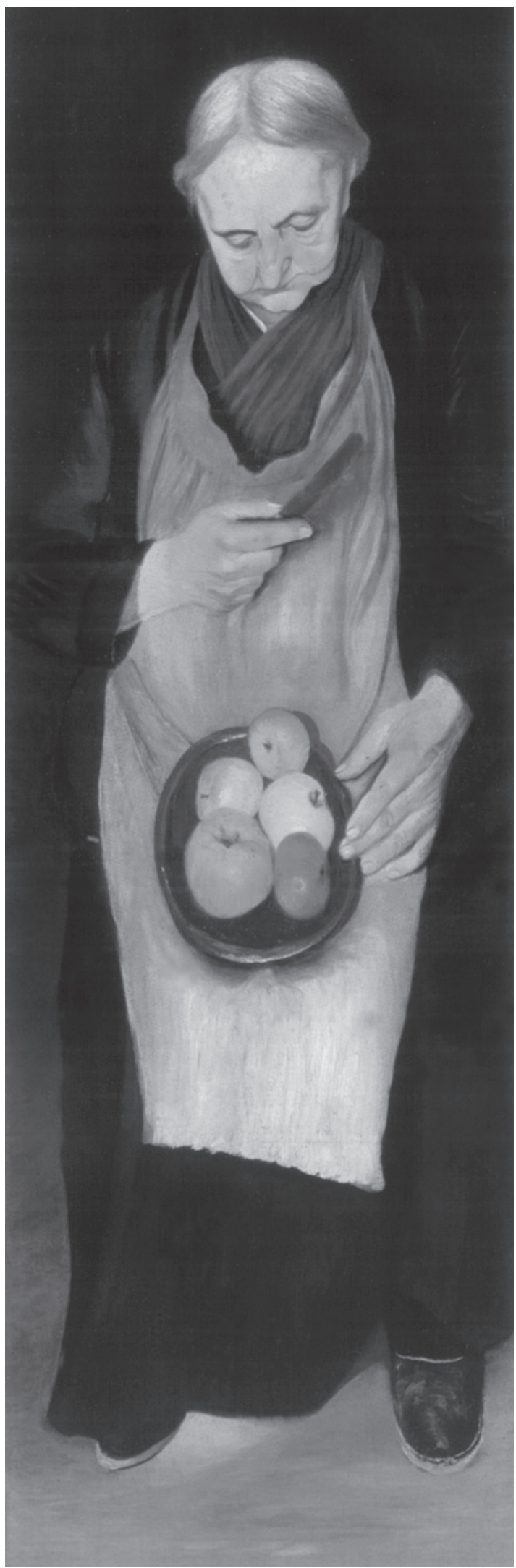

3. Csontváry Kosztka Tivadar:

Almát hámozó öregasszony, 1894.

Budapest, Magyar Nemzeti Galéria, ltsz.: 50.439 
kétdimenziós vásznon. Nyilván nem egy, a korát jócskán meghaladó szerkesztési eljárással, de ráérezve a két és a három dimenzió természete közt feszülő problémára már korai képein is intuitív módon keresett újszerü megoldásokat a térbeli alakzatok síkban történő ábrázolására. Ez a látványszerkesztési séma később is visszatér életművében néhány figuratív képe mellett (Szerelmespár; Randevú, mindkettő 1902-1903) tájképein is, mint például az Athéni utca (1904), vagy az Aldozati kő Baalbekben (1906) címü alkotásokon.
A fenti példa is jól mutatja, hogy Csontváry térszerkesztési kísérletei sajátos, egyéni utakat kereső szemléletet feltételeznek. Próbálkozásait nagy valószínűséggel a kor táj- és életképfestészetében elterjedt kihasított, kimetszett komponálási sémákkal, valamint a fragmentált látvánnyal szembeni ellenérzés táplálta. ${ }^{12}$ Ezt bizonyítja, hogy saját korának a térre vonatkozó festészeti gyakorlatát más helyütt is kritizálta. Raffaello Stanzáira és az „élő távlatra” vonatkozó megjegyzéseiben például így ír: „Nem ismeri az ember a levegő távlatát nem ismeri a csil-

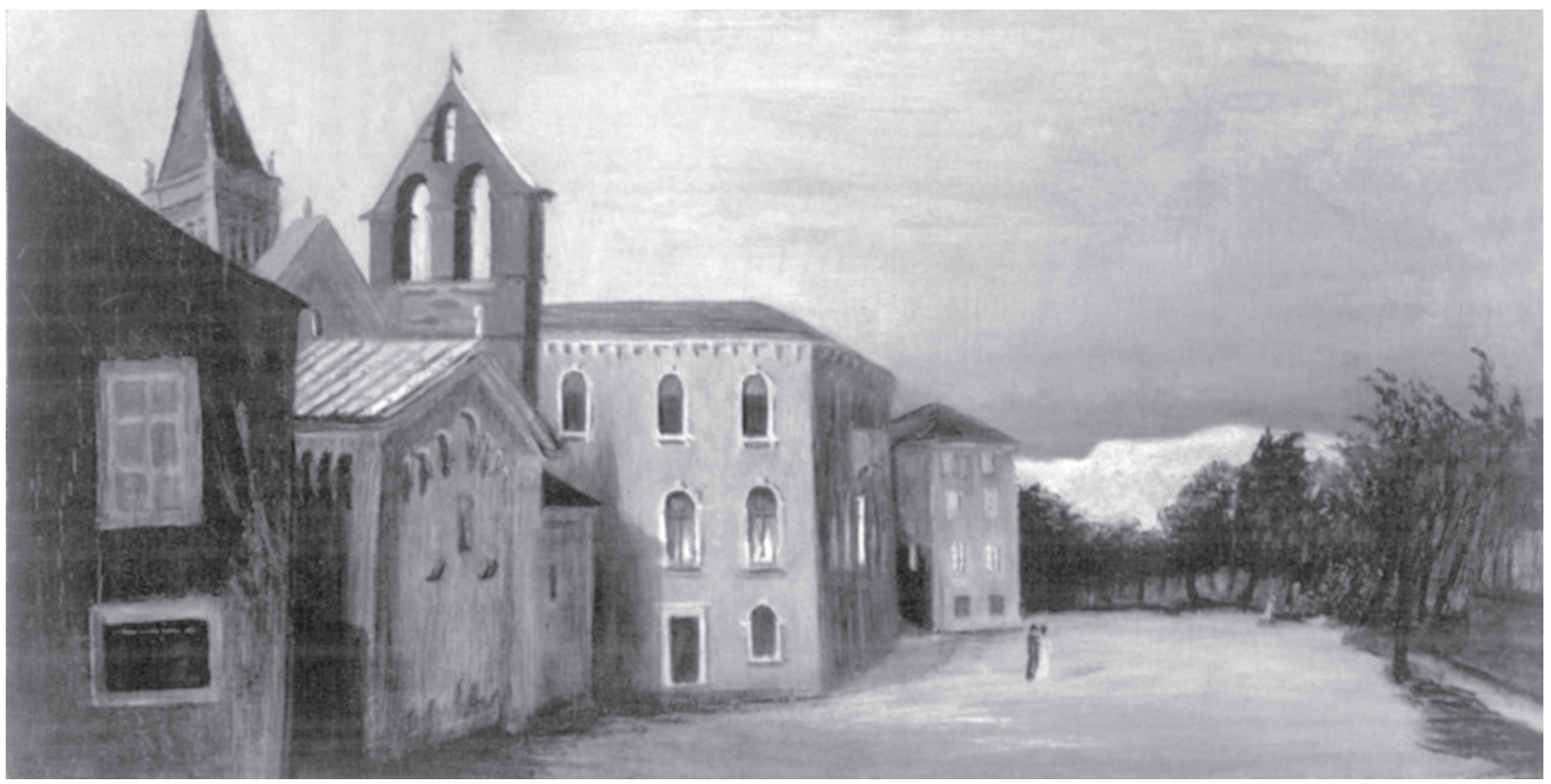

4. Csontváry Kosztka Tivadar: Holdvilágos éj Trauban, 1899. Magántulajdon

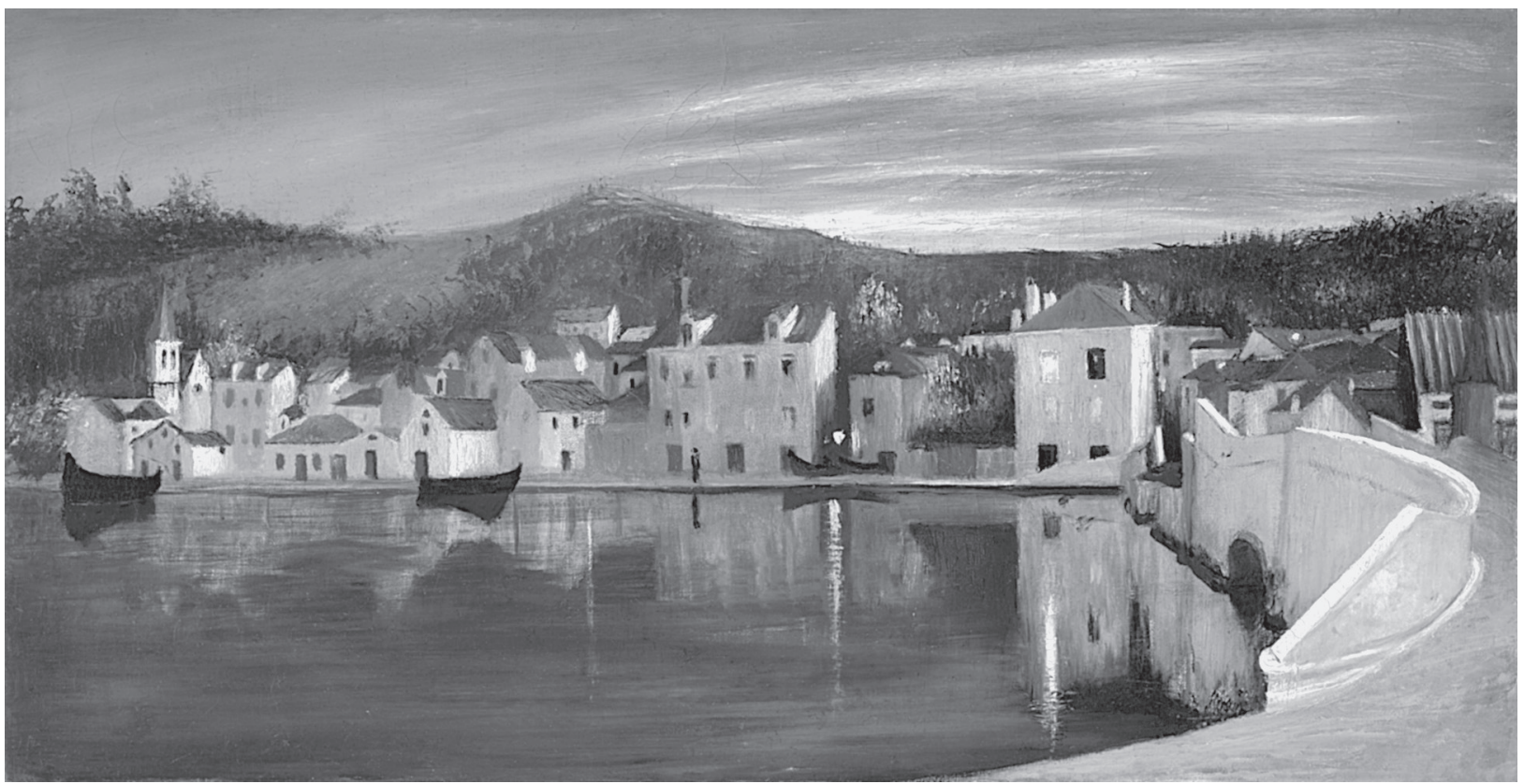

5. Csontváry Kosztka Tivadar: Traui tájkép naplemente idején, 1899. Magántulajdon 
lagos ég távolságát $\mathrm{s}$ ha mi a csillagok távolságát nem ismerjük úgy a Hold mint a Nap távolában optikailag csalódunk. Mert a távlat nem ismeret, nem tudás nem akadémiai tanulmány, hanem önkívüli érzés útján jut kifejezésre eredményben pedig isteni ihlethez van kötve."13

Feltételezhető, hogy ez a sajátos, a térábrázolásra vonatkozó művészi igény hívta életre Csontváry képpárjait is, amelyek elsősorban Trogirban, Castellammaréban, illetve Taorminában készült festményei között bukkannak fel 1899 és 1903 között. Korábban már Romváry Ferenc is felfigyelt e képpárok létezésére, de a ténynek nem tulajdonított nagyobb jelentőséget. ${ }^{14}$ Pedig feltünő, hogy ezek a darabok azon túl, hogy azonos témát dolgoznak fel, szinte kivétel nélkül megegyező méretűek. Ez azért is figyelemre méltó, mert a méreteket tekintve Csontváry életműve meglehetősen nagy változatosságot mutat. Standard méretek egyáltalán nem szerepelnek az œuvre-ben, sőt méretazonosság is csak elvétve, szinte kizárólag az alább tárgyalt párdarabok esetében fordul elő.

\section{Trogir}

A Trogirban készült festmények helyszínét tanulmányozva merült fel először, hogy a festő öt dalmát képe közül négy párdarabnak tekinthetô. ${ }^{15} \mathrm{E}$ pár- darabok legfontosabb sajátossága, hogy azonos helyszínt ábrázolnak más-más nézőpontból. A nézőpont megválasztása ugyanakkor sohasem „véletlenszerü", a festő a második kép megfestésekor 180 fokkal változtatja meg nézőpontját. Mintegy odavissza megfesti az adott helyszínt. ${ }^{16}$

Ez történik a Holdvilágos éj Trauban (1899) és a nemrég felbukkant Traui tájkép naplemente idején (1899) esetében, ahol a müvész az óvárost és a vele szemben lévő Ciovo szigetet összekötő híd lábától festi meg mindkét képet. Az első vászon elkészülte után a korábban a háta mögött elhelyezkedett látványt örökíti meg; az első kép esetében északi, utóbbinál déli irányba festi az elé táruló tájat (4-6. kép).

A Délelőtti kis plein air Trauban (1900) és a Délutáni vihar Trauban (1900) esetében egy másik sémát alkalmaz Csontváry. E két festmény a Trogirral szemben elhelyezkedő Ciovo sziget partvonalának keleti és nyugati sarokpontjairól készült. Egy tengely két végpontját alkotják a nézőpontok, a tengely pedig egyúttal az egyes darabok tájolását is kijelöli: Csontváry a keleti csúcsról nyugatra tekintve festette a délelőtti kis plein airt, a nyugatiról pedig keleti irányba tájolta a délutáni vihart (6-8. kép).

A két képpár ugyanakkor egy nagyobb egységet is alkot. A négy festmény a négy égtájat is jelöli nézetével, miközben mindegyik alkotás más-más napszakban, más-más fényviszonyok között örökíti meg a dalmát város tengerpartját. A négy napszak és a négy égtáj a következő: délelőtt - nyugat; délután - kelet; alkonyat - dél; éjszaka - észak.

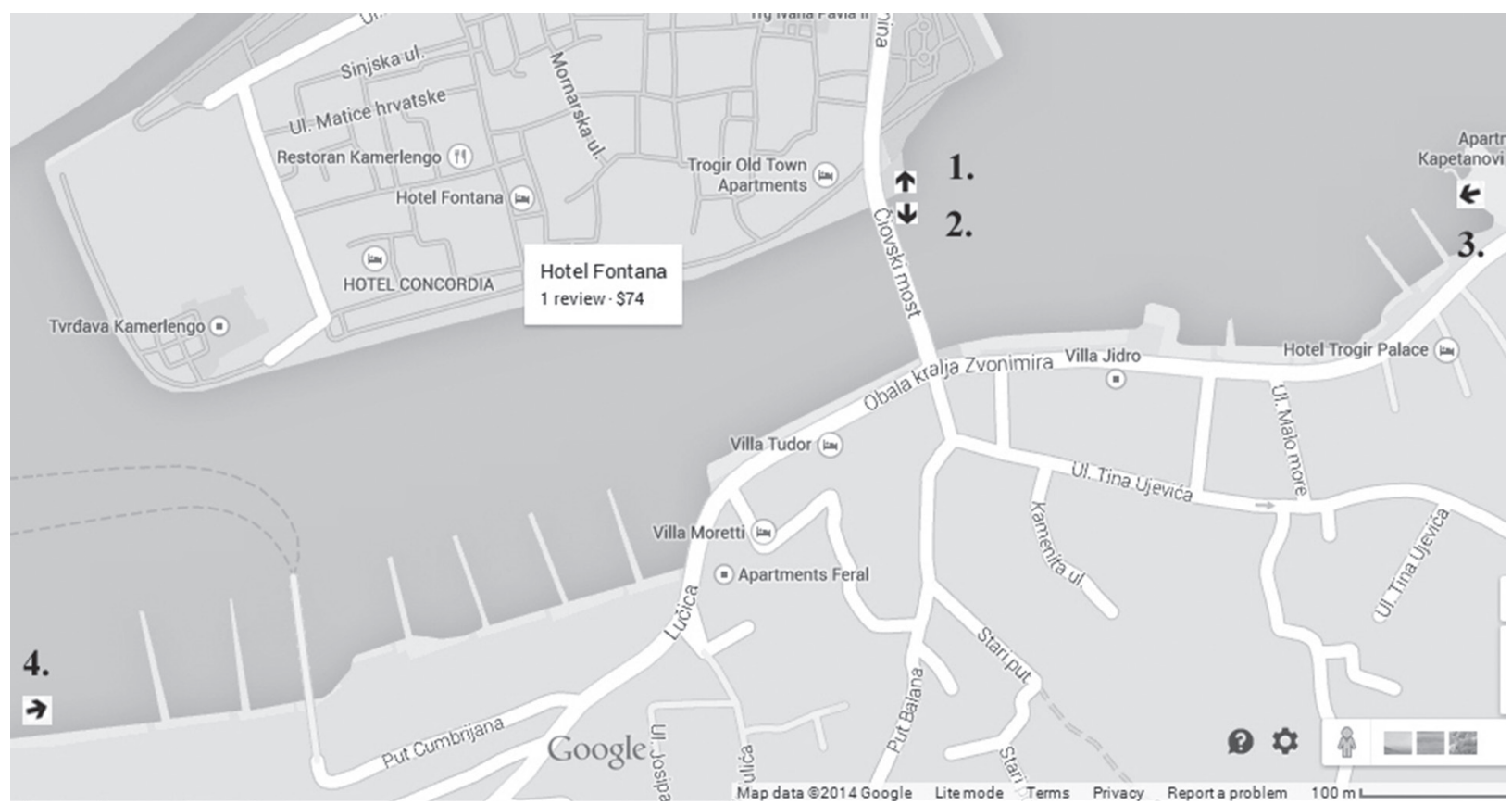

6. A trogiri képek készültének helyszine és tájolásuk: 1. Holdvilágos éj Trauban (1899), 2. Traui tájkép naplemente idején (1899), 3. Délelőtti kis plein air Trauban (1900), 4. Délutáni vihar Trauban (1900) 
A kis halászvároshoz eddig négy festményt kötött a Csontváry-kutatás. Közülük három tekinthető plein air-tanulmánynak: a Világitó éj Castellammaréban (1901), az Esti halászat Castellammaréban (1901) és a Castellammare di Stabia (1902). ${ }^{17}$ Ahogy a trogiri négy kép, ezek ugyancsak tájolt darabok. Csontváry a városka korzóját tengelyként használva déli, illetve északi irányba festette azokat.

A Világitó éj Castellammaréban és a Castellammare di Stabia egyértelmúen párdarabnak tekinthetők, hisz a város sétányának ugyanazon pontjáról készültek. A két kép festésének pontos helye ma is tökéletesen azonosítható. A Világító éj Castellammaréban bal szélén található piros homlokzatú palota ugyanaz az épület, mint ami a Castellammare di Stabia jobb szélén is felbukkan. Csontváry itt is a trogiri első sémát követte: 180 fokkal elfordította festőállványát, s mintegy panorámaképként rögzítette az északi, illetve a déli irányban elé táruló látványt (9-10. kép).

A harmadik castellammarei plein air-tanulmány (Esti halászat Castellammaréban) érdekessége, hogy tájolását tekintve megegyezik a Világitó éj Castellammaréban címü képpel, azaz a város déli oldalát mutatja. E két festmény esetében egy északdéli irányú tengelyen mozgott a festő. A két alkotás egymástól körülbelül 500 méter távolságban készült. Az esti halászat alkonyati fényben mutatja a várost, a Világitó éj Castellammaréban pedig éjszakai beállítás, ahol a kép bal szélén álló piros palota melletti - a képen már nem látható, de ma is álló - földszintes ház mögül tör be a fény a korzóra (11-12. kép).

E két változat egy azonos motívum egyenértékű feldolgozását jelentheti eltérő fényviszonyok mellett. Az első verzión a fő megvilágítást a város fölé tornyosuló hegy sziluettje körül megjelenő napfény adja. A második változat esetében a múvész válla mögül, a festmény bal széle felől érkező holdsu-

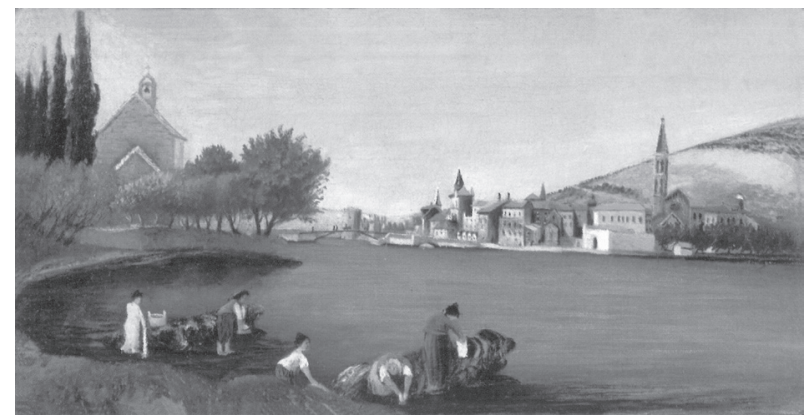

7. Csontváry Kosztka Tivadar: Délelötti kis plein air Trauban, 1900. Budapest, Magyar Nemzeti Galéria, ltsz.: FK 3888

gár lesz a kép motívumait beragyogó fény forrása. E két alkotásán Csontváry olyan beállításokat tanulmányoz, melyek fényviszonyai később egy festménybe sürítve jelennek majd meg a Holdtölte Taorminában (1901) és kiérlelt formában a Visszatekintő nap Trauban címün (1899). ${ }^{18}$

\section{Taormina}

Taorminában valószínűleg három alkalommal járt Csontváry. Először 1901-1902 telén, castellammarei tartózkodásának évében. ${ }^{19}$ Másodszor 1902 végén, 1903 elején, harmadszor pedig A taorminai görög színház romjai megfestésekor, azaz 1904-1905 telén. Az első út során tanulmányokat készített. A második a színház megfestésének kudarcával zárult. ${ }^{20}$ Csak a harmadik látogatás hozta meg számára a sikert az athéni és az egyiptomi kitérőt követően, immár a „világító színek" használatának elsajátítása után.

Az első és a második taorminai tartózkodás alatt készült művekből ma nyolc ismert. A „tetemes” mennyiség jelzi, hogy Csontváry valóban komoly előtanulmányokat folytatott a görög színház témá-

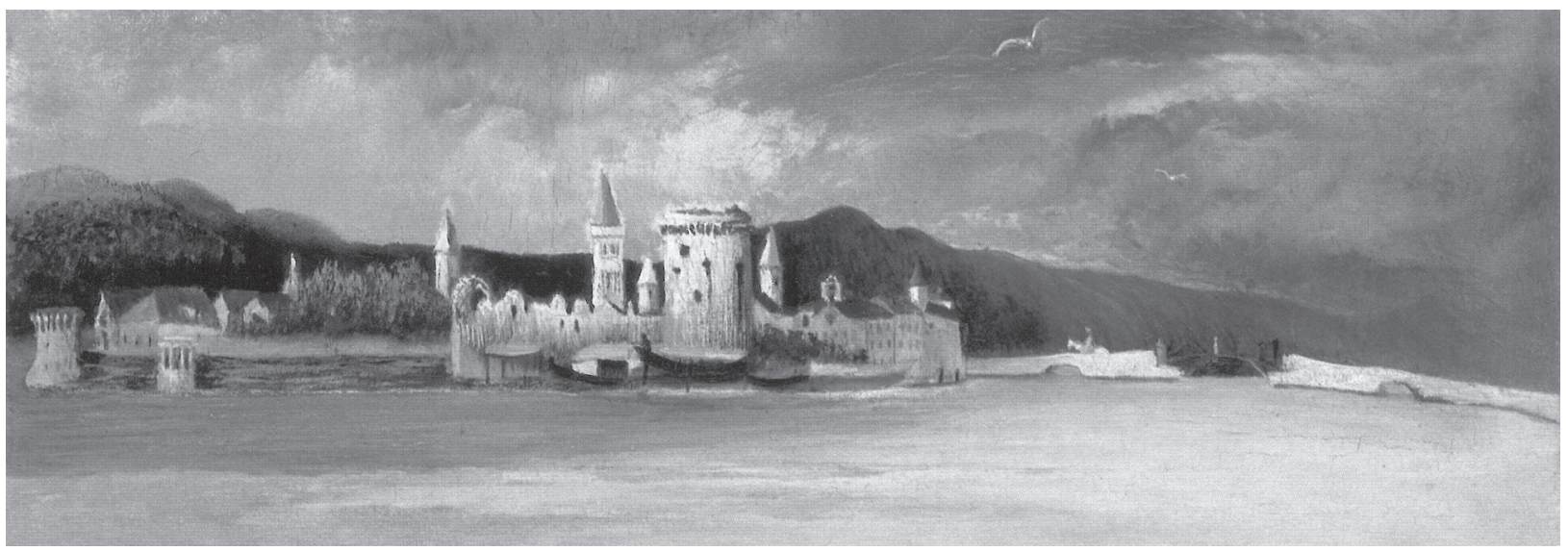

8. Csontváry Kosztka Tivadar: Délutáni vihar Trauban, 1900. Debrecen, Dr. Antal Péter gyüjteménye 


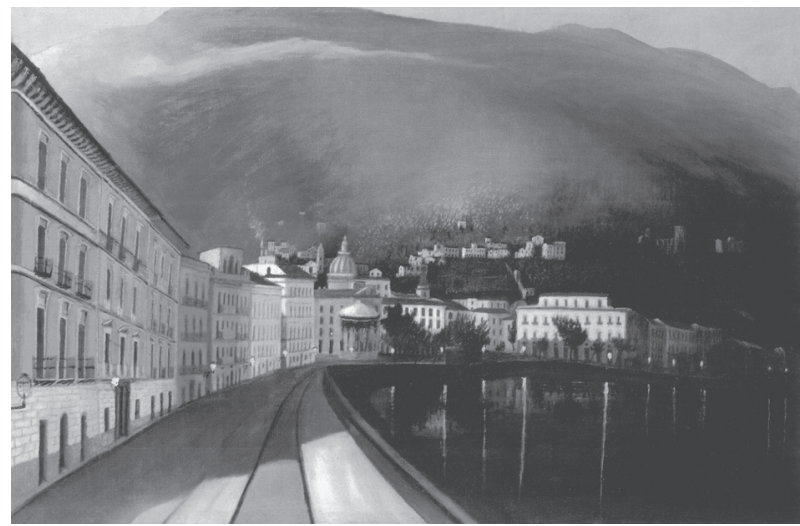

9. Csontváry Kosztka Tivadar: Világító éj Castellammaréban, 1901. Budapest, Dr. Szegedy-Maszák Mihály gyüjteménye

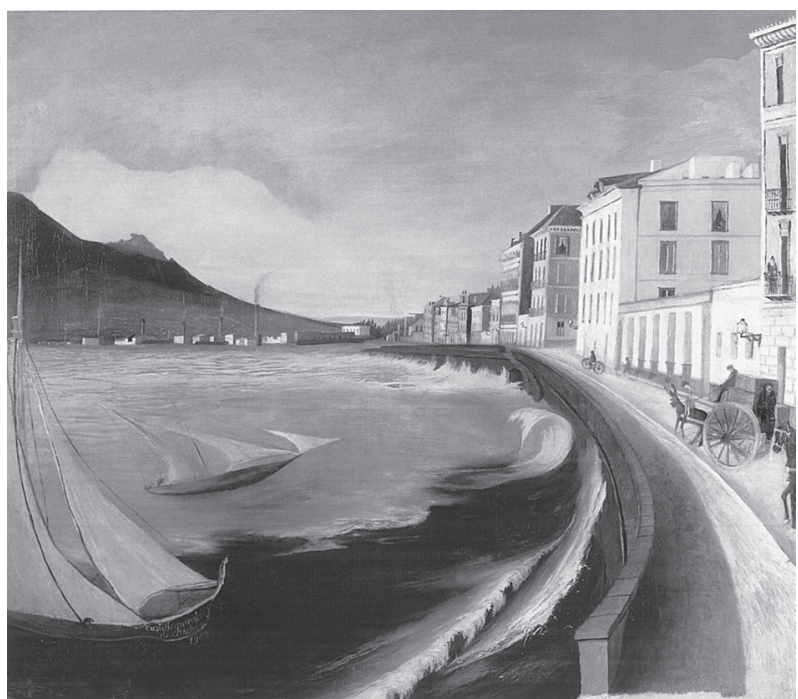

10. Csontváry Kosztka Tivadar: Castellammare di Stabia, 1902. Pécs, Modern Magyar Képtár, ltsz.: 69.162

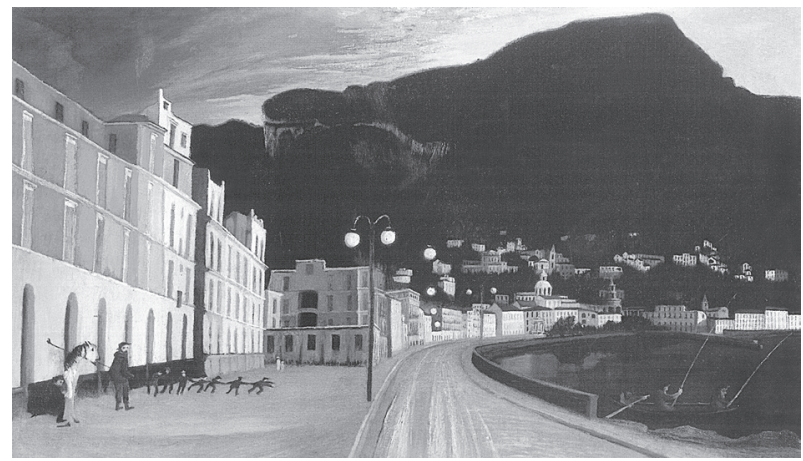

11. Csontváry Kosztka Tivadar: Esti halászat

Castellammaréban, 1901. Pécs, Város Önkormányzata, Csontváry Múzeum, Pécs, letét

ját illetően, mert ezek a képek kivétel nélkül keletnyugat tájolásúak, akárcsak $A$ taorminai görög színház romjai.

Keletkezésük helyszínét tekintve két csoportra oszthatók ezek a plein air-tanulmányok. Közülük

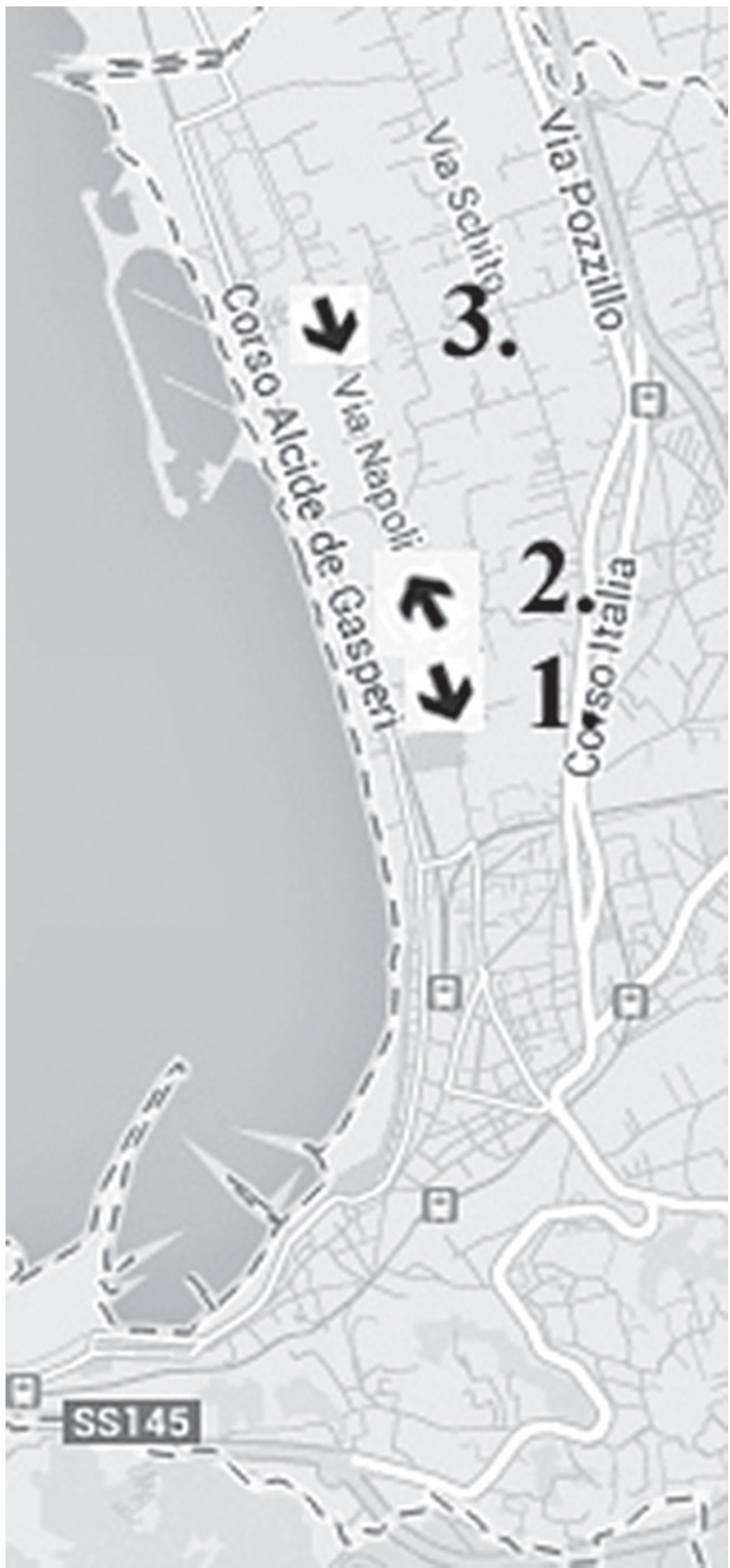

12. A castellammarei képek készültének helyszine és tájolásuk: 1. Világító éj Castellammaréban (1901),

2. Castellammare di Stabia (1902), 3. Esti halászat Castellammaréban (1901)

három - a Füstölgó Etna (1901 körül, lappang), a Holdtölte Taorminában (1901) és a Mandulavirágzás Taorminában (1902) - a hegy oldalában fekvő városhoz felvezetô útról készült. A két utóbbi kép annak ellenére, hogy nézőpontjuk nem teljesen azonos - légvonalban húsz, a tengerhez mért magasságukat tekintve körülbelül öt méter eltérés van a két pont között -, mégis párdaraboknak tekinthetők. 
A Trogirban és a Castellammaréban készült képpárokhoz hasonlóan itt is 180 fokkal fordítja el a festöállványt Csontváry (13-14. kép).

A csoport harmadik tagja, a Füstölgó Etna lappangó alkotás, amely csak archív fotóról ismert. A kép beállítása a Mandulavirágzás Taorminában-éval megegyező, ugyancsak nyugatra tekint, s a városba felvezető út egy másik részletét ábrázolja. Pontosabb analízisét azonban a képről ismert egyetlen archív fotó nem teszi lehetővé.

A második taorminai tárgyegyüttes négy festménye már fent a városban készült. Mindegyik a települést kelet-nyugati irányban átszelő Corso Umbertóhoz köthető. Mintha egy séta négy

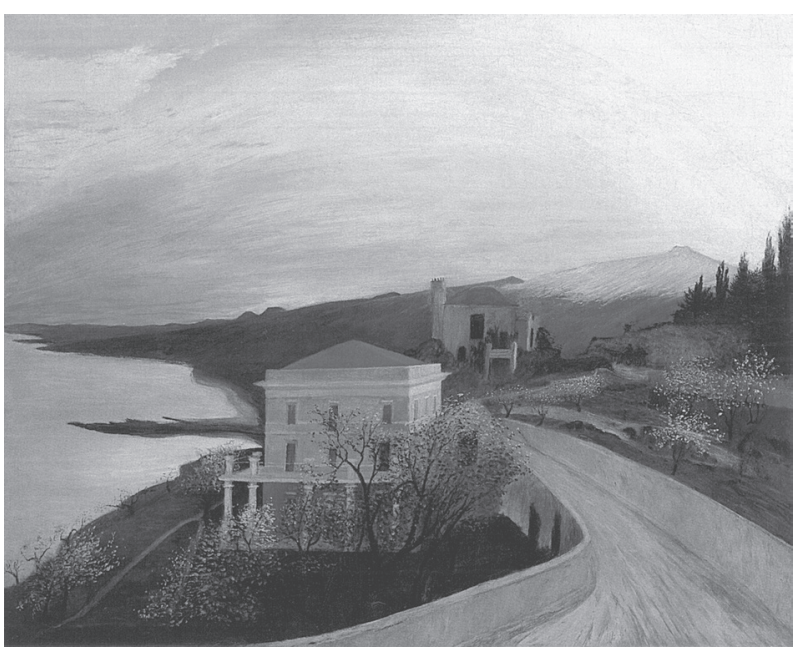

13. Csontváry Kosztka Tivadar:

Mandulavirágzás Taorminában, 1902.

Pécs, Modern Magyar Képtár, ltsz.: 83.115 stációját rögzítette volna a művész. Hasonlóan a castellammarei két, déli tájolású alkotáshoz, egy egyenesen mozogva készítette a képeket. A kiindulási pont a korzó keleti végén álló Palazzo Corvaia (A Palazzo Corvaia Taorminában, korábban Olasz halász, 1901 körül). Az itt készült festmény a boltozatos kapun át kelet felé tekint. Ezt követi a városka szívében található Piazza Sant Agostino (A Piazza Sant Agostino Taorminában, korábban Olasz város, 1901). A térről készült kép nyugat felé tájolt. ${ }^{21} \mathrm{~A}$ harmadik kép a korzó nyugati végén, a várost a Porta Catanián át elhagyva szemünk elé táruló látványt rögzíti. Ez a mú ugyancsak nyugat felé tekint, s ma Mandulavirágzás (1901 körül) címen ismert. S végül a negyedik alkotás a várostól nagyjából egy kilométerre, a Cataniába vezető hegyi úton született $\mathrm{He}$ gyi út Taormina felé tekintve (korábban Villa Pompeji, 1901), amely a város irányába visszapillantva rögzíti a látványt (15-20. kép).

A négy festmény készültének helyszíne tehát itt is egy tengelyre füzhető - akárcsak az Esti halászat Castellammaréban és a Világító éj Castellammaréban, vagy a Délelőtti kis plein air Trauban és a Délutáni vihar Trauban. A tengely két végpontjában készült alkotás keleti tájolású, míg a két közbülső pontról a művész nyugati irányba festi a képeket.

A három helyszínen készült, tizenhárom vizsgált alkotásból összességében kitünik, hogy Csontváry képpárjai hasonlatosak a csak körmozgást végző fényképezőgép által készített körpanorámákhoz. Míg azonban a felvevőgép végtelen számú kép készítésére alkalmas, addig a festő - a nyilvánva-

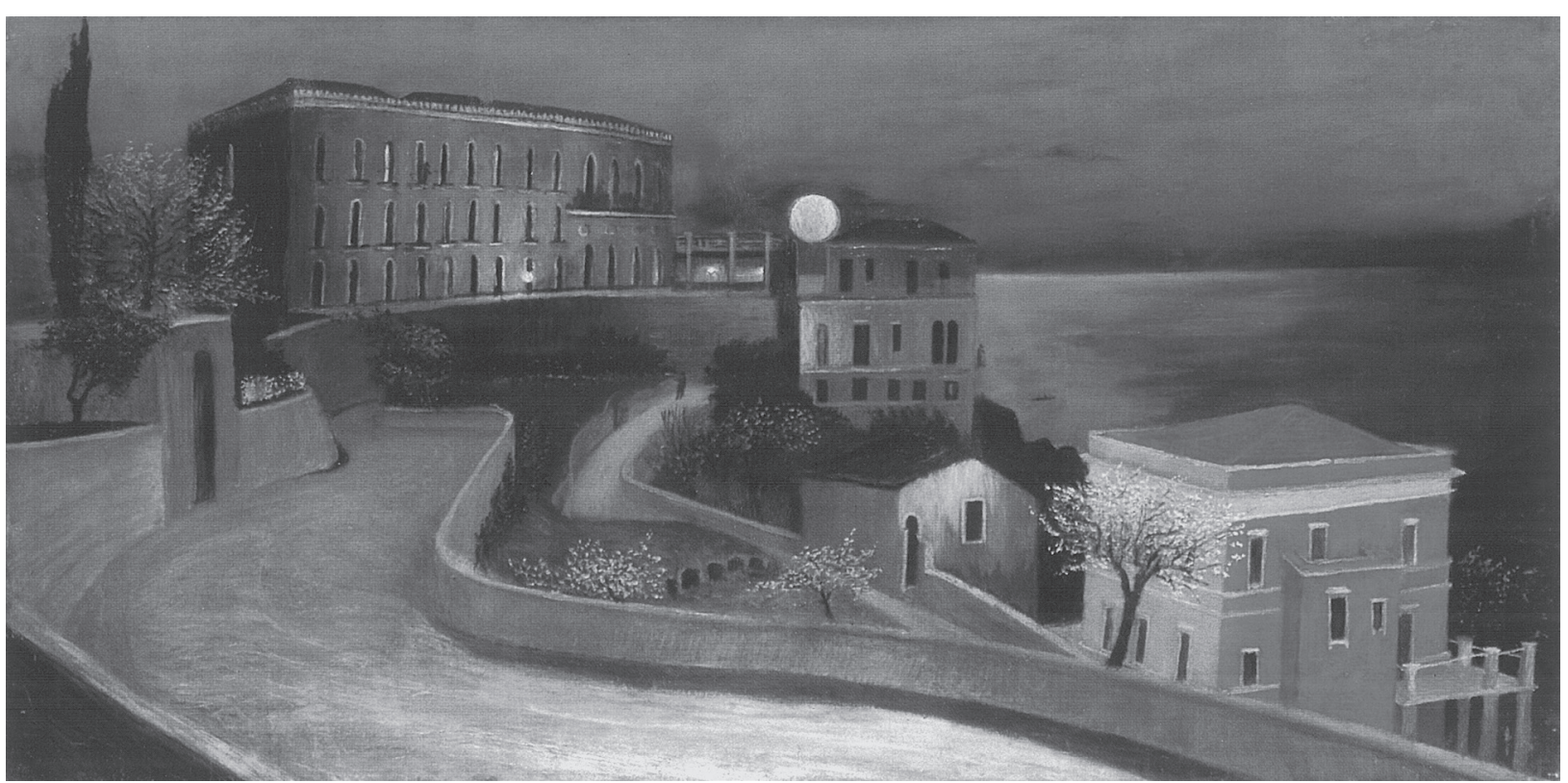

14. Csontváry Kosztka Tivadar: Holdtölte Taorminában, 1901. Magántulajdon 
ló gyakorlati nehézségek okán - két „kockából” illesztette össze panorámaképeit. Mind az azonos pontokról, mind pedig az egyenes tengely mentén készített képpárok széles látószög rögzítésére képesek. Így készültek nemcsak a trogiri, hanem a castellammarei és a taorminai plein air-tanulmányok is. Jól láthatóan nem egyszeri kísérletről van szó. A festő éveken át alkalmazza ezt a technikát.

Ez a gyakorlat a térábrázolás új útjait kereső aspirációkkal hozható összefüggésbe. Lényegi újítás ez a kor plein air-gyakorlatához képest, melyben Csontváry a fragmentált látvány kiterjesztésére tesz kísérletet. Âllandó szándéka ez a festőnek. „,... Ö́t csak a rendkívüli, nagyszerű kilátások vonzották..." - írja róla Lehel Ferenc. ${ }^{22}$ Nem pusztán egy tájrészlet vagy fényjelenség megörökítése a cél: képpárjaival a teljességre törekszik, 360 fok képben történő transzponálására.

\section{Az ido"}

A „teljesség” képbe történő transzponálása nem csupán a térbeniség vonatkozásában jelenik meg Csontváry korai tájképein. A tér mellett az idő komponensével is rendre kísérletezik a festő. Akárcsak a tér kérdése esetében, már a vizsgált időszak előtt felbukkannak ilyen irányú kísérletek az életmúben. Példa erre a festő Pompeji Have című (1887-1898) alkotása, melyet gyakran Casa del Chirurgo, néha A chirurgus háza a Vezúvoal néven emleget a szakirodalom (21. kép). A festmény azonban nem a sebész házát ábrázolja. A képen az ugyancsak Pompejiben található Casa del Fauno romjai láthatóak. ${ }^{23}$

Életrajzának egyik változatában Csontváry maga is megemlékezik erről a festményről: „Pompejiben az első festménnyel a távlatot kerestem $\mathrm{s}$ megtaláltam a Vezúvval a háttérben (a Havéval elötérben)...${ }^{24} \mathrm{~A}$ távlata valóban különös, s nem pusztán azért, mert a romos villa kertje mögött a város sorsát megpecsételő Vezúv rajzolódik ki. Korábban a két mellső oszlop által határolt helyiség padozatán feküdt az a mozaik, amely III. Dareiosz és Nagy Sándor isszoszi ütközetét ábrázolta. A mű már a 20. század elején is a nápolyi Museo Archeologico egyik fő látványosságának számított ${ }^{25}$ (22. kép).

Valószínü, hogy sem a helyszín megválasztása, sem a kép középtengelyes kompozíciója nem a véletlen műve. A romok között megbúvó padozat az antik görög és római kultúra egyik legfigyelemreméltóbb személyiségét és pillanatát idézi meg. A festmény nem pusztán a látvány által nyújtott távlat hordozója, s maga a festő sem csupán a fizikai beállítás aspektusára gondolt, amikor a „távlatot kerestem" kifejezést használta. Csontváry a mozaik

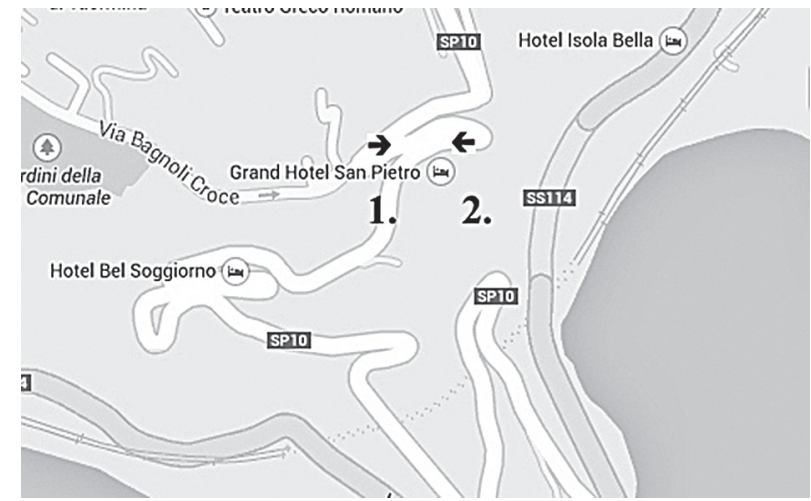

15. A Taorminába vezető hegyi úton készült alkotások helyszine és azok tájolása: 1. Mandulavirágzás Taorminában (1902), 2. Holdtölte Taorminában (1901)

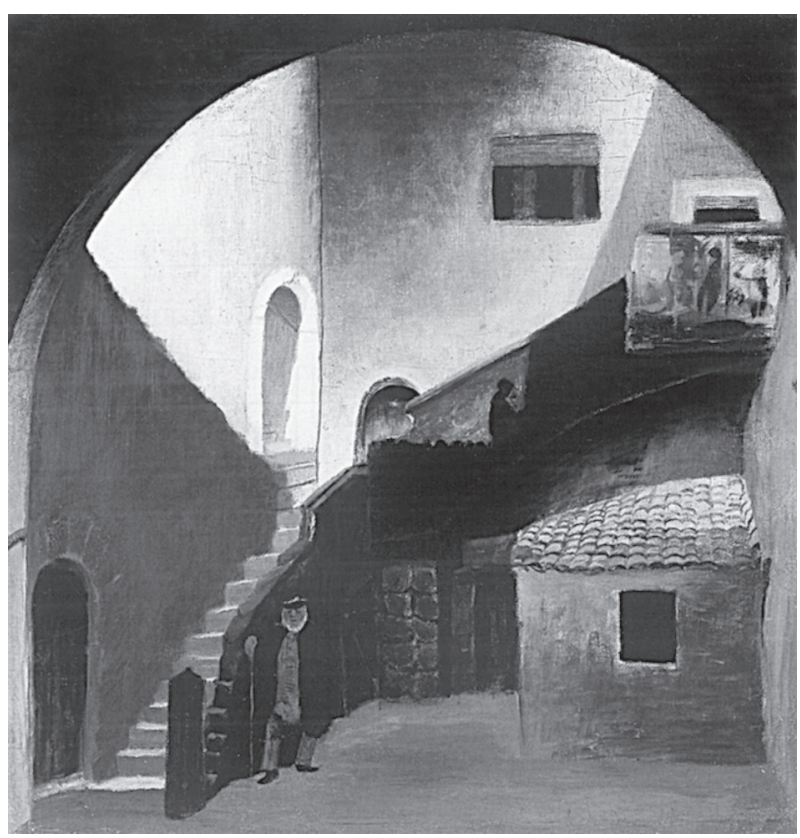

16. Csontváry Kosztka Tivadar: Palazzo Corvaia (Olasz halász), 1901 körül. Magántulajdon

beemelésével a fizikai mellett egy másik távlatot is megnyitott a képen. A romváros és a Vezúv motívumát összefogó perspektíva mellett „történelmi mélysége" is van a képnek, amely az antik világ egykor volt dicsősége és Pompeji temetői hangulata között feszül. A tájkép ezzel egyszersmind történelmi képpé is nemesül, melyen a festő nem mulasztja el kifejezésre juttatni az antik görög-római kultúra felett érzett sajátságos erkölcsi-morális ítéletét sem. ${ }^{26}$

A történelmi távlat állandó eleme lesz majd Csontváry festészetének, de néhány évvel később - épp a plein air-tanulmányok esetében - másfajta megoldásokat is alkalmaz a képi idő bővítésére. Szembetűnő, hogy a képpárok egyes darabjai sohasem azonos napszakot örökítenek meg. Délelőtt, délután, naplemente, éjszaka: a címek rend- 
re eltérő napszakokat jelölnek mind Trogir, mind Castellammare és Taormina esetében. Csak feltételezhető, hogy a tengely megválasztása és a nézőpont 180 fokos elforgatása a Nap vagy éppen a Hold járását követi. Az égitestek mozgása, az egyes időfázisok egymásutánisága azonban egyértelmüen arra enged következtetni, hogy az pillanatnyi benyomások és hangulatok helyett a fény terjedé- sének útját és így az idő múlását, annak egy tágabb időintervallumát rögzíti a párokban. A szenzuális élmények pillanatnyisága helyett a hajnal és az est, a délelőtt és a délután, vagy éppen a nappal és az éjszaka változó fényviszonyainak együttes, szimultán jellegü ábrázolására törekszik a képpárokban. Csontváry lényegében kiterjeszti a képi időt az öszszetartozó darabok segítségével.

A napszakok váltakozása a képpárokon:

Trogir

Holdvilágos éj Trauban (1899) - Traui tájkép naplemente idején (1899)

Délelőtti kis plein air Trauban (1900) - Délutáni vihar Trauban (1900)

alkony - est
délelőtt - délután

Castellammare

Castellammare di Stabia (1902) - Világító éj Castellammaréban (1901)

a két azonos tájolásún:

Esti halászat Castellammaréban (1901) - Világító éj Castellammaréban (1901)

nappal - est

alkony - est

Taormina - hegyoldal

Mandulavirágzás Taorminában (1902) - Holdtölte Taorminában (1901)

alkony - est

Taormina - Corso Umberto

Palazzo Corvaia (Olasz halász, 1901 körül) - Piazza Sant Agostino (Olasz város, 1901) - Mandulavirágzás (1901 körül) - Hegyi út Taormina felé tekintve (Villa Pompeji, 1901) mind a négy kép nappali, szórt fényben

A párdarabok tehát nem pusztán panoramatikus igényü tájábrázolások, hanem azok egy meghatározott időintervallum rögzítésére is szolgálnak. A darabok ezért külön-külön nem, csak együttesen értelmezhetők helyesen. Csak így lehet pontosan meghatározni a rajtuk megjelenő fényviszonyokat, és csak így lehet helyesen értékelni a plein air-tanulmányok életműben betöltött szerepét is. Ellenkező esetben csupán a festmények jelentésrétegeinek felső szintjéig, egyfajta sejtelmes, misztikus tájképfestészet jegyeinek konstatálásáig juthatunk el. Sőt, így a tanulmányok és a korai főmúvek pontos kapcsolata sem értelmezhető. De ha a párdarabokat együtt vizsgáljuk, láthatóvá válik, hogy a rajtuk rögzített tér- és fényviszonyok megjelennek az első főmúveken is. A tanulmányok és az azokat követő nagyobb lélegzetü alkotások kapcsolatából Csontváry festészetének mélyebb összefüggéseire is következtethetünk.

\section{II.}

\section{CSONTVÁRY SZIMULTÁN TECHNIKÁJA}

Csontváry kiterjeszti a teret és az időt képpárjain. De a festő nem elégszik meg ennyivel: összegezni próbálja korábbi tanulmányait. Az eredmény a fény jelentősége körül körvonalazódik majd a későbbi múvekben, legkorábban az 1902-ben készült Visszatekintő nap Trauban címü festményen (23. kép).

Már a helyszínválasztás sem lehet véletlen e kép esetében. Bár a művésztől hátramaradt dokumentumokban sehol sem találunk erre utalást, Trogir jelentőségét a település történelmi vonatkozásai adhatták számára. A dalmát város szimbolikus helyszíne a magyar történelemnek, amely természeti adottságai által nyújtott menedéket a tatárok elől menekülő IV. Bélának. ${ }^{27} \mathrm{~A}$ város múltja egyben történelmi perspektívát is ad a képnek, amit a festő egészen a jelenig terjesztett ki azzal, hogy a festményt az Országháznak ajánlotta. ${ }^{28}$ Ahogy a Casa del Fauno számára az isszoszi csata és a füstölgő Vezúv ad historikus távlatot, úgy nyújt hasonló történelmi perspektívát e képen Trogir és a magyar államiság kapcsolata. ${ }^{29}$

Már Németh Lajos is felfigyelt e festmény különös, kettős megvilágítására: „A harangtorony és a városházépület között izzó égitest: a visszatekintő nap. Helyzete meglepő, hisz sugarai bal oldalról vetik fényüket a falakra, itt pedig a háttérben tünik el. Vagy tán nem is a nap, hanem a felkelő hold lenne az izzó korong? Vagy Csontváry szakított a 
természeti objektivitással, és festői, hangulati megoldásból szabadon módosította az égitestek helyzetét, az atmoszferikus jelenségeket?"30

A lemenő nap fénye nyugat-délnyugat felől, azaz jobbról esik be a város főterére. A tornyon és a mellette álló városháza homlokzatán ez pontosan érzékelhető. A toronyóra 4 óra 37 percet mutat. ${ }^{31}$ Öröknaptárak szerint ez a naplemente a január 20. körüli időszakra datálja a festményt (ekkor a napnyugta időpontja 16:50), amely egyben telihold idöszaka is Trogir környékén. ${ }^{32} \mathrm{~A}$ hold fel is bukkan a városháza és a harangtorony között délkelet felől a képen. A lemenő nap és a kelő hold tehát egyszerre van jelen a festményen. Ráadásul mindkettő a napszaknak megfelelően, topografikusan helyes pozícióban. Csontváry tehát nem „szakított a természeti objektivitással", ahogyan azt Németh Lajos gondolta. Ellenkezőleg, a valóságból merített, amikor kettős megvilágítást használ a festményen. Csontváry ezzel a sémával teremti meg annak a hatásnak az alapját, amit Lehel Ferenc is megfigyelt a festő képein: „,... a testeket több pontból világítja meg, amivel bizonyos villogó hatást idéz elő. ... Ugyancsak kellemetlen érzést kelt az ő képein, hogy a testek körvonalai néha világosabbak a lokáltónusoknál. Végül az opalizálás kedvéért felületesen kevert festékből a világos színek, főleg a fehér vonásról vonásra kivillognak." ${ }^{33}$

A kettős megvilágítás nyomán egyes motívumokat helyi színekkel, másokat markáns, sokszor túlhajszolt reflexszínekkel ábrázolt. „Ő a hajnal és az alkonyat megvilágítását kedvelte különösen. De hajnali és alkonyati világítása nem mártja be szokványos vörössel és sárgával az egész tájat... Csontváry a kelő és a bukó nap első és utolsó sugarát ragadja el, mely a tájnak csak egy-egy pontjára tüz. $S$ mialatt a vidékre a reggel vagy az est szürkületének hangulata terül rá, egy test szinte indokolatlanul, de annál lenyűgözőbben pirosan parázslik." ${ }^{\prime 34}$

Ez a beállítás tehát nem egy egyszerű „hangulati megoldás", ahogy Németh írja. Csontváry konzekvensen ragaszkodik a valósághoz. Nem átírja, hanem keresi azokat a jelenségeket, amelyek a természetben a kettős megvilágítás lehetőségeit hordozzák magukban. A kettős megvilágítás sémájának előzményeit a képpárokban találjuk meg. Csontváry e "villogó hatás" kikísérletezésére és megvalósítására használta fel az egyes fázisképeket. Megkereste vagy kivárta a számára szükséges fényhatásokat, melyeket azután szimultán módon vitt fel az összegző képre.

Az idő „rabul ejtésének” technikájában azonban az összegző darab és a képpárok között van egy jelentős különbség. Csontváry a plein air-tanulmányok esetében párok felállításával iktatja ki képei- ből a pillanatnyiságot. A Visszatekintő nap Trauban az égitestek számának kettőzésével teremt időtlenséget. A keletről érkező holdra visszatekintő, az abban visszaköszönő nap látványa egy képbe süríti az égitest által bejárt utat. Egyszerre jelenik meg a reggel, valamint az alkony stációja, keretbe foglalva az égitest egész napos útját az égen.

\section{A kettős megvilágítás genezise}

A képpárok és az összegző alkotás viszonyán túl a kettős megvilágítás gyakorlatának genezise is tökéletesen nyomon követhető a plein air-tanulmányokban. A séma kidolgozása Taorminán keresztül

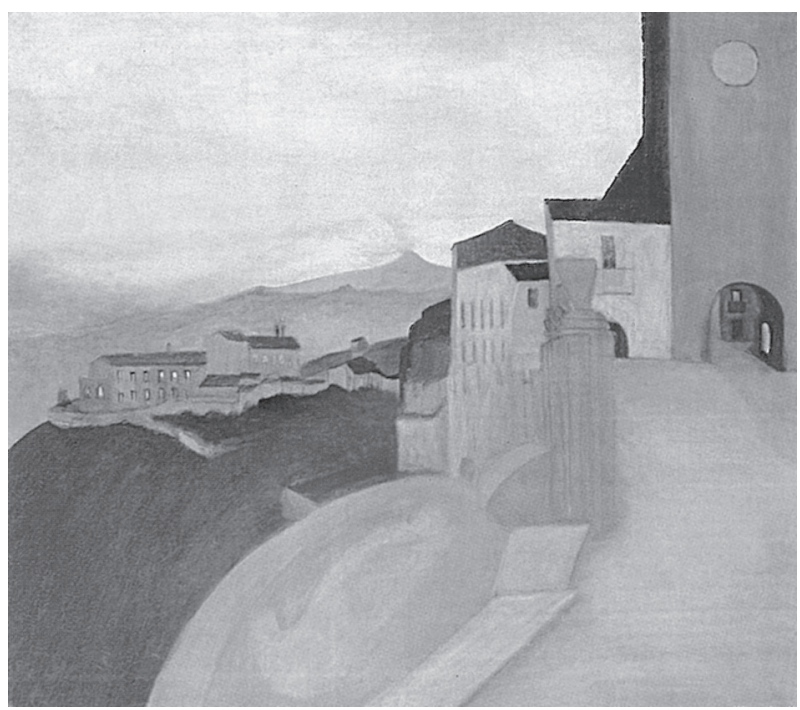

17. Csontváry Kosztka Tivadar:

Piazza Sant Agostino (Olasz város), 1901.

Budapest, Magyar Nemzeti Galéria, ltsz.: $94.2 \mathrm{~T}$

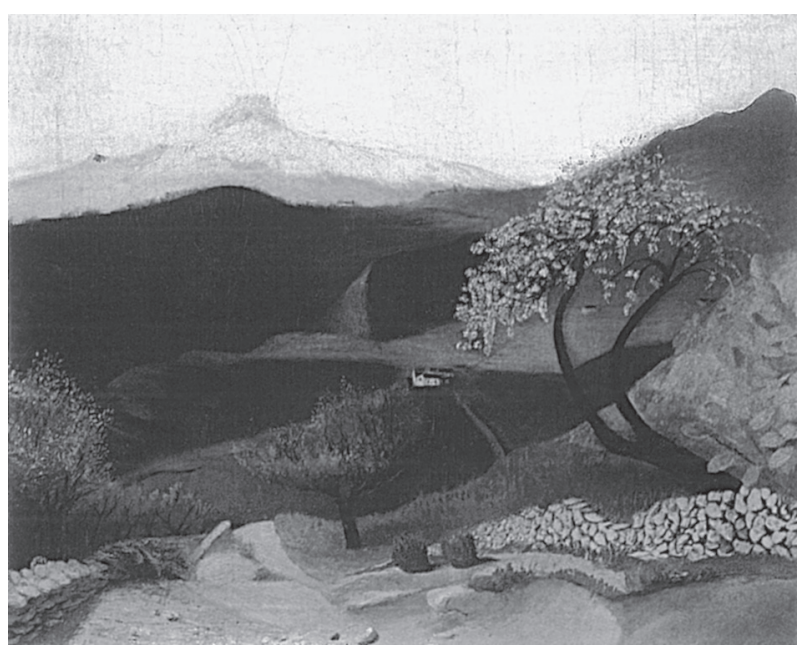

18. Csontváry Kosztka Tivadar: Mandulavirágzás, 1901 körül. Miskolc, Herman Ottó Múzeum, ltsz.: P 77.64 


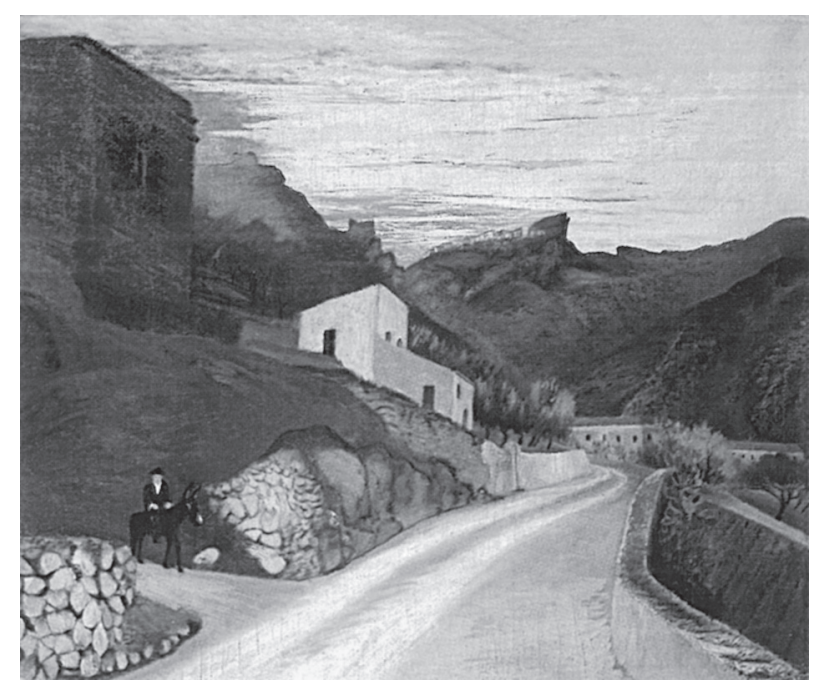

19. Csontváry Kosztka Tivadar:

Hegyi út Taormina felé tekintve (Villa Pompeji), 1901. Stockholm, János Mártony gyüjteménye

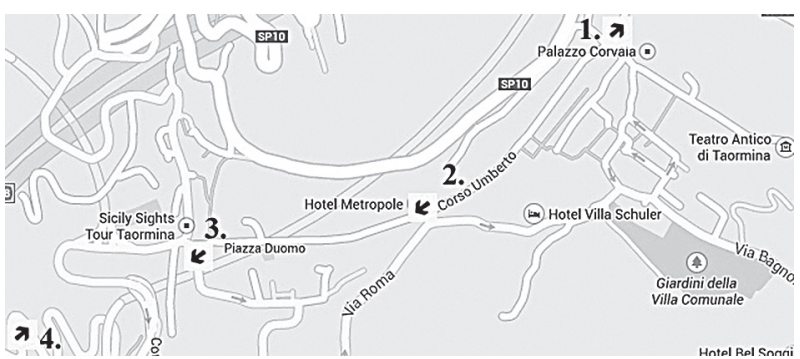

20. Taorminában, a Corso Umberto vonalán készült képek helyszine és tájolása: 1. Palazzo Corvaia (Olasz halász,

1901 körül), 2. Piazza Sant Agostino (Olasz város, 1901),

3. Mandulavirágzás (1901 körül), 4. Hegyi út Taormina felé tekintve (Villa Pompeji, 1901)

visszanyúlik egészen Castellammaréig. Csontváry ez utóbbi helyszínen találhatott rá a kettős fényhatásban rejlő lehetőségekre, mégpedig a két déli tájolású kép, az Esti halászat Castellammaréban és a Világító éj Castellammaréban festése során. A Visszatekintó nap Trauban sajátos fényviszonya - a háttérből és az előtérből érkező fény együttes alkalmazása ugyanis itt jelenik meg először festészetében, ekkor még csak két külön tanulmányban. ${ }^{35}$

Castellammare és Trogir között Taormina jelenti az összekötő elemet. A Holdtölte Taorminában, valamint párdarabja, a Mandulavirágzás Taorminában fényviszonyait tanulmányozva arra a következtetetésre juthatunk, hogy azok - akárcsak a castellammare-i déli tájolású két festmény - egymást követő napszakokban készültek. A mandulavirágzás az alkonyt, a holdtölte pedig az est beálltát ábrázolja. A két képen jól megfigyelhető egy klasszicista épület, a Villa Pietro, ${ }^{36}$ amelynek az út felőli homlokzatát mindkét alkotáson fény világítja meg. A Mandulavirágzás Taorminában-on a nyugaton alábukó nap fényében izzik a ház fala. A Holdtölte Taorminában-on a szürkületből az éjszakába átforduló este utolsó, immár csak az égbolt által visszavert napsugarai világíthatják meg a villát és az előtér útfelületét. Mindeközben a háttérben felbukkan a hold, ahogy a Visszatekintó nap Trauban-on is.

Megvilágításukat tekintve ez a két szicíliai darab ugyanazt a sémát követi, mint amit a kicsivel később készült trogiri összegző kép: a festmény középpontjában felbukkanó hold, valamint az alkotás előteréből visszatekintő alkonyi fény együttesen jelölik a nap által bejárt utat. Azonban van egy jelentős különbség a trogiri összegző kép és a taorminai darabok között. Ahogyan a korábban tárgyalt párképeket, ezt a két festményt is a panoramatikus látvány igénye hívta életre. Pontosan értelmezhető az alkonyi kép ismeretében, hogy honnét kap fényt a Villa Pietro nyugati homlokzata. Mintha Csontváry végletes következetességgel próbálta volna igazolni a képen látható fényviszonyokat. A képpárból együttesen bontakozik ki a fény vándorlásának története, amit a dalmát kisváros főterén már egy alkotásba sürít a festő. A trogiri összegző darab esetében Csontváry lemond a taorminai képpárnál megfigyelhető panoramatikus látvány igényéről. Lemond a logikai következetességről, arról, hogy egy másik festményt hívjon segítségül az oldalról beeső fény hitelességének igazolására. Túllép a következetességből adódó, panoramatikus látvány igényének korlátain, s „önkényesen” csakis a kettőzött megvilágítás eszközét alkalmazva zárja képébe az időt.

Így az eddigiek összegzése valami újnak a kezdetét is jelenti Csontváry festészetében. Összehasonlítva a Visszatekintő nap Trauban-t az azt megelóző tanulmányokkal, jól látható hogyan távolodott Csontváry a panoramatikus igény következetességétől, s vele attól az ideától is, miszerint a tájkép teljessége a fizikai tér teljességének ábrázolásával jelentene egyet. A trogiri összegző kép jól mutatja, hogy a tér és az idő fogalmának valós, fizikai kategóriáitól egyre inkább a fény jelentősége felé terelődik figyelme, a rezgő színekről vallott megfigyeléseinek, elképzeléseinek gyakorlatba történő átültetésére. „A nap rezgő helyzetben két részből áll s folyton halad láthatóan a szemlencséje. A szemlencse lapos világoszöldeskékes színű korongja fényes mely mögött vannak a bíborvörös párák amelyekből alakulnak ki a világító és melegítő sugarak..." ${ }^{37}$ - írja, s ettől az időszaktól kezdve megszállottan keresi a több fényforrású témákat, a villanyvilágítást, a vízesések szórt fehér fényét, a tábortüzek fényjátékát. A kettős megvilágítás gyakorlata lesz a fó kérdése festészetének a kairói „erfunden”-ig és a görög úton szerzett meghatározó tapasztalatokig. 
A vizsgált plein air-tanulmányok párdarabokba rendeződő panorámaképek, melyeket a tér és az idő kiterjesztésére és rögzítésére fundált ki a festő. A Visszatekintő nap Trauban e kísérletek kiérlelt eredményének tekinthető. Szimultán módon itt egyesül először Csontváry időre és térre vonatkozó összes korábbi megfigyelése, a képpárokra jellemző fényanalízis, valamint a kettős megvilágítás gyakorlatának ötlete. Csontváry egy egyszerü tájképből szimbolikus képet generál ezekkel az eszközökkel. A komponensek, amelyek a plein air-tanulmányokban még csak részben vagy rejtve fedezhetők fel, a Visszatekintő nap Trauban képén már kristálytiszta szerkezetben állnak előttünk. Ez a szerkezet pedig a nap útját és alighanem Csontváry „napút” fogalmát és annak jelentését is láthatóvá teszi. A Visszatekintő nap Trauban credója korai tájképfestészetének, melyben a nap és rajta keresztül „,az isteni akarat”, a „Pozitívum” tevékenységének állít emléket a festő.

\section{A napút fogalma és annak kapcsolata Csontváry festészeti gyakorlatával}

Csontváry kozmológiája és életbölcselete, valamint az életbölcseletnek alárendelt festészeti gyakorlat közötti kapcsolat kulcsmomentuma a művész „napút” fogalma. Ez a kifejezés Csontváry terminus technicusa. Nem csupán azért, mert az isteni gondviseléssel vagy, ahogy a festő nevezi a „Pozitívum"-mal hozható kapcsolatba, hanem azért is, mert ez a fogalom a "Pozitívum” szimbólumával, a Nappal, a napfénnyel s így végső soron festészetének gyakorlati oldalával áll szoros összefüggésben.

Különös, de a „napút” kifejezés pontos körülírását sehol sem találjuk meg a Csontváry-dokumentumokban. Ennek oka valószínűleg a szó és a szó által jelölt szimbólumrendszer áttételes jelentésrétegeiben keresendő. Viszont szinte minden írásában találunk elejtett utalásokat, életbölcseletéből eredő megjegyzéseket. Így ír például a Baalbekről, a „világ legnagyobb napút festményéről”: „E munka létrehozza az ember és az Isten között az összekötő szellemi kapcsolatot, melynek segítségével a megoldhatatlan háttér, a levegő távlata az élő perspektívával, a napút távlat megközelíthetetlen szín (...) ragyogó pompával lett megoldva." ${ }^{38}$ A napút távlat tehát az Isten és az ember között teremtett szellemi kapcsolat eszköze. Majd később: „Az isteni Gondviselés... Kinevezett a világ legnagyobb festőjének és kezembe adta a plein-air rajztudást a levegő távlatának az érzését $\mathrm{s}$ a napút festészetnek a színezetét. ... S azt amit az egész világ keresett megtaláltuk a Pozitívummal a világfejlesztő Mesterhez való kapcsolatot." ${ }^{39}$

$\mathrm{Az}$ utóbbi szövegrészletekből kitűnik, hogy Csontváry „napút távlata” szoros kapcsolatban áll sajátos plein air-gyakorlatával. A mester a két fogalmat egymásra „csúsztatva”, értelmüket átfedésbe hozva alkalmazza: mindkettőt az isteni gondviseléstől kapta, hogy festményeivel a kor emberét viszszavezesse a "Pozitívum” által kijelölt útra. A két fogalom egy olyan technikát fed, mellyel kapcsolat teremthető Isten és ember között. Sőt, olyan tudást jelöl, melyet isteni beavatás útján szerezhet meg néhány kiváltságos. „A Pozitívum amint azt már kifejtettem csak a legritkább esetben érintkezik az emberrel akkor amikor az emberművelődés történelme holtpontra jut ez történik a 15-ik században amikor a Pozitívum plein-airbe avatta Raffaelt és most amikor a plein-air festésben új fordulatot hozott. $^{\prime \prime 0}$

A „napút”, illetve a „plein air” fogalmának szoros kapcsolatát nemcsak a festő írásai igazolják, hanem Csontváry kortársának, Lehel Ferencnek egy anekdotája is: „....midőn Kairóban a naplemente tanulmányozása közben ráakadt »a sokat keresett napút színeinek világító fokozatára«, e fölfedezést Hollósy festővel táviratilag közölte. »Pleinair erfunden Tschontwary « - szólt a sürgöny, mit a müncheni magyar mesternek éjjel kézbesítettek, hogy aztán mérgére ne tudjon újra elaludni. A sürgönyt egyébként a magyar kultuszminisztériumnak is föladta." 41

A fentiekhez hasonló következtetésekre juthatunk a festő monográfusainak megfigyeléseiben. A Csontváryval foglalkozó kutatók abban szinte mindannyian egyetértettek, hogy a "napút” és a „plein air" tudatos és kitartó tanulmányozásával a különböző fényhatásokat igyekezett tájképeibe transzponálni a művész. Arra azonban, hogy a festés gyakorlatára vonatkozólag ez a "sürítés" mit is jelenthet, sehol sem találunk pontos meghatározást. Lehel Ferenc párhuzamban a fenti idézettel, a „napút" kifejezést lényegében a plein airrel azonosítja, hangsúlyozva, hogy ennek helyes alkalmazása sokkal összetettebb feladat Csontváry számára, mint ahogy azt a kortársai elképzelhették volna. Hogy mit is ért ezalatt, azt azonban már nem részletezi a szerző. ${ }^{42}$

Németh Lajos a terminus megfejtését illetően egyetért Lehellel, annyiban kiegészítve őt, hogy Csontváry számára a lefesteni kívánt motívum is teljesen mást jelent, mint a legtöbb pályatársa számára. Esetében a motívum nem pusztán látvány, hanem a festő mágikus világképén átszürt transzcendens valóság. ${ }^{43}$ De hogy miként jut érvényre a „napút" távlata, és miként válik tökéletessé a „plein 
air"-gyakorlata Csontváry festői felfogásában, azt egyikük sem válaszolta meg pontosan.

Összevetve a képpárokon kikísérletezett technikát és a „napút” fogalmának a festő kozmológiájában betöltött szerepét, nyilvánvalóvá válik, hogy Csontváry a 19. század második felétől általánossá vált szabadban festésnek és a látvány hangulatának gyors rögzítési technikáját kívánta „tökéletesíteni". Plein air-gyakorlata sajátos természetlátásából és világszemléletéből ered, amely homlokegyenest eltér a naturalizmus pozitivizmusától és az impresszionizmus szenzualizmusától. Csontváry saját kozmológiájából kiindulva érlelte ki különös festői gyakorlatát. E folyamat tanúi a fentebb bemutatott képpárok, melyekben összegződik Csontvárynak az időre és a térre vonatkozó összes megfigyelése, és e megfigyelések festői gyakorlatba történő átültetése: a képpárok széles látószögü tájábrázolása, a "történelmi perspektíva” alkalmazása, a képi idő kiterjesztésének technikája és a kettős megvilágítás használata. A „napút”-festészet szimultán technikája által a fény és a fénnyel átitatott táj a maga teljes univerzális valóságában - a lét minden dimenzióját felfedő módon - jelenik meg nála.

Csontváry különös személyisége jelentôs tetteket vitt végbe abban a müvészeti időszakban, amely a klasszikus tér fogalmának szétrombolásával vette kezdetét a 20. század elején. Festészetével olyan új megoldásokat teremtett, amelyek ugyan összevethetők más művészek speciális komponálási elveivel, de végső soron senki máséihoz nem foghatók. Megoldásai és a megoldások kiérlelése olyan nagy ívű tervet jelöl, amely aligha fedezhető fel kortársainak művészi elképzeléseiben.

\section{III.}

\section{KIS KITÉRŐ: CSONTVÁRY DALMÁT ÉS OLASZ TANULMÁNYÚTJAI}

A kettős fényhasználat sémájának genezise Csontváry tanulmányútjainak pontos sorrendjét, valamint a művek készültének időrendiségét is megmutatja. Az már a korábbi kutatás számára is világos volt, hogy a plein air-tanulmányok közül a négy trogiri darab készült a legkorábban (1899-1901). Keletkezésének idejét tekintve e négy tanulmánykép mellé sorolta a szakirodalom a Visszatekintó nap Trauban-t is annak ellenére, hogy azt a festő maga datálta 1902-re. ${ }^{44}$ A trogiri, castellammarei és taorminai tapasztalatokat összegző festmény azonban, ahogy arra elemzésemben utaltam valóban 1902ben készülhetett.
A négy trogiri plein air-festményt követik a Castellammaréban (1901-1902), valamint a Taorminában készült alkotások. Ez utóbbi tárgyegyüttes hét stúdiumát azonban további két csoportra, a hegyoldalon készült három képre és a Corso Umbertón festett négy müre kell osztani. A különválasztást stiláris okok teszik szükségessé.

Csontváry három alkalommal járt Taorminában. A harmadik úthoz két, a görög színházat ábrázoló képet társított eddig a kutatás, a kisebbiket (Kis Taormina, 1904) a végleges mű előtanulmányaként számon tartva. Ez utóbbi valóban a görög színház előtanulmánya, de nem a nagy képpel egy időben született. Jóval valószínúbb, hogy Csontváry a második taorminai tartózkodása során, azaz a Corso Umberto tengelyén készült négy képpel egy időben festette azt.

Feltúnő, hogy a Kis Taormina mellőzi a végleges alkotás távlatát, „levegojét” és „ünnepelt” világító színeinek intenzitását. A festő pozíciója eleve meggátolja a színház mögötti pazar látvány bemutatását. A Kis Taormina magas horizontja a figyelmet inkább a színház romjainak részleteire tereli. A kép hátterének részletei ugyanakkor meglepően közel állnak a korzón készült csoport harmadik eleméhez, a Mandulavirágzáshoz. Mindkettő nyugati tájolású, így a festmények háttere szinte teljesen megegyező domborzati képet mutat. Az Etna hósapkája, valamint az előtte elnyúló hegylánc kékes-szürkés tónusai szinte teljes egészében megegyeznek a két képen. Sőt, a Kis Taormina előterének motívumai is a négyes csoport darabjaival mutatnak hasonlóságot, főként az utolsó darabbal, a korábban Villa Pompeji néven ismert képpel. Részletezőbb, „,naturalisztikusabb” kidolgozásuk, barnás színárnyalataik szoros kapcsolatot, azonos keltezést feltételeznek.

Stílusát tekintve a Kis Taormina sokkal közelebb áll a Corso Umberto 1903-ban készült négy képéhez, mint az 1904-1905-ös végleges változathoz. Nem zárható ki, hogy épp a Kis Taormina az a kép, melynek kapcsán Csontváry ekképpen ír: „.... nagy motívumhoz hozzá nem nyúlhattam - a rajz arányában megállapodni, a rendkívüli világító erőt kihozni nem tudtam..." ${ }^{45}$ Illetve másutt: „,...Taorminából kétévi tartózkodásom után világkörüli útra kellett mennem és viharos tengeren napokig bolyongva mindent felejtenem" ${ }^{46}$

A dalmát és az olasz tanulmányutak során festett képpárok keletkezésének sorrendje a kettős megvilágítás genezise alapján:

Trogir - négy tanulmánykép (1899-1900)

- Holdvilágos éj Trauban (1899)

- Traui tájkép naplemente idején (1899) 
- Délelötti kis plein air Trauban (1900)

- Délutáni vihar Trauban (1900)

Castellammare di Stabia - öt kép (1901-1902)

- Világító éj Castellammaréban (1901)

- Esti halászat Castellammaréban (1901)

- Castellammare di Stabia (1902)

- Egy este Castellammaréban (1902, lappang), tévesen Egy este Kairóban (1904)

- Öreg halász (1902 körül)

Taormina, első út - a hegyoldalon készült három kép, valamint Scilla látképe (1901-1902)

Scilla látképe (1901)

- Füstölgő Etna, (1901 körül, lappang)

- Holdtölte Taorminában (1901)

- Mandulavirágzás Taorminában (1902)

Trogir, második út - a kettős megvilágítás öszszegzése (1902)

- Visszatekintố nap Trauban (1902)

Taormina, második út - a Corso Umbertón készült négy kép, valamint a színház első ismert változata (1902-1903)

- A Palazzo Corvaia Taorminában (1902-1903), tévesen Olasz halász (1901 körül)

- A Piazza Sant Agostino Taorminában (19021903), tévesen Olasz város (1901)

- Mandulavirágzás Taorminában (1902-1903), tévesen 1901 körül

- Hegyi út Taormina felé tekintve (1902-1903), tévesen Villa Pompeji (1901)

- Kis Taormina (1903)

Taormina, harmadik út - a színház megfestése (1904-1905)

- A taorminai görög színház romjai (1904-1905)

IV.

\section{CSONTVÁRY FESTŐI GYAKORLATA 1897 ÉS 1903 KÖZÖTT}

Némi szarkazmussal kijelenthető, hogy Csontváry egyáltalán nem erőltette meg magát a fenti képek helyszíneinek kiválasztása során. Festményei - néhány kivételtől eltekintve - népszerü turisztikai célpontokról készültek, amelyek látványosságaik, esetleg fürdőjük miatt frekventált települések voltak a 19. és a 20. század utazói számára. A kutatás már korábban is a 19. századi tájképfestészet hagyományaira, romantikus előképekre vezette vissza a festő „stúdiumainak” témáit. ${ }^{47}$ Szabó Júlia a 19.

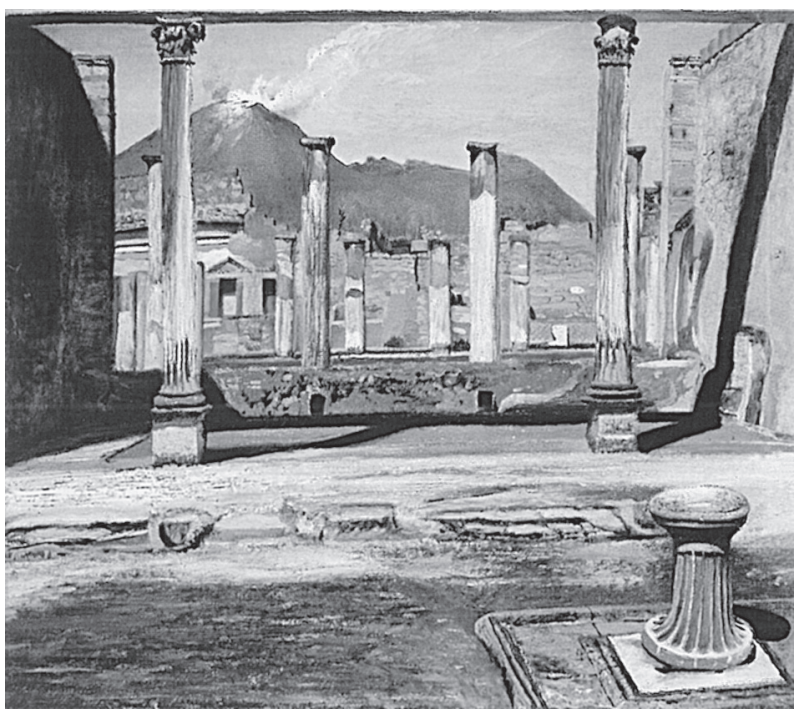

21. Csontváry Kosztka Tivadar: Casa del Fauno tévesen Casa del Chirurgo, 1887-1898.

Budapest, Dr. Szegedy-Maszák Mihály gyüjteménye

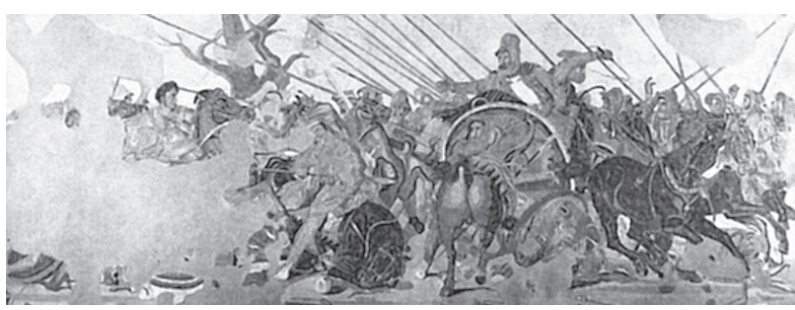

22. III. Dareiosz és Nagy Sándor isszoszi ütközete, Nápoly, Museo Archeologico

század etalonszerű "grand-tour"-jának kései példáját látja Csontváry tanulmányútjaiban, a müvészt pedig „a XIX. század eleji klasszicizáló, romantikus vedútafestők utódá" -nak nevezi. ${ }^{48}$ Csontváry azonban nem vakon követte a romantika hagyományait. Bár a kor szokványos útiterveit követte, kizárólag azokat a helyszíneket festette, amelyek saját művészi elképzeléseiben kiemelt fontossággal bírtak. Taormina, Mostar vagy Baalbek mellett Trogir, a Tarpatak, Selmecbánya, Hortobágy, Szigetvár olyan történelmi perspektívával rendelkeznek, melyek egyéni világszemléletének sarkalatos pontjait jelentik.

Vizuális „közhelyek”-ről nem csupán a vidék vagy helység megválasztása kapcsán beszélhetünk. Csontváry szűkebben vett témáit vizsgálva is konvenciókra bukkanunk. Keresnünk sem kell e képek készültének pontos helyszíneit; lényegében belebotlik az ember a képtémákba. Alkotásai frekventált, forgalmas és könnyen megközelíthető pontokról készültek. Korzók, sétányok, terek adják festményei témáját, amelyek ma is az adott város, település leglátogatottabb, legfrekventáltabb részei. Szabadi Judit egyenesen turisztikai „közhelyekről” beszél e képek motívumai kapcsán. ${ }^{49}$ Csontváry va- 


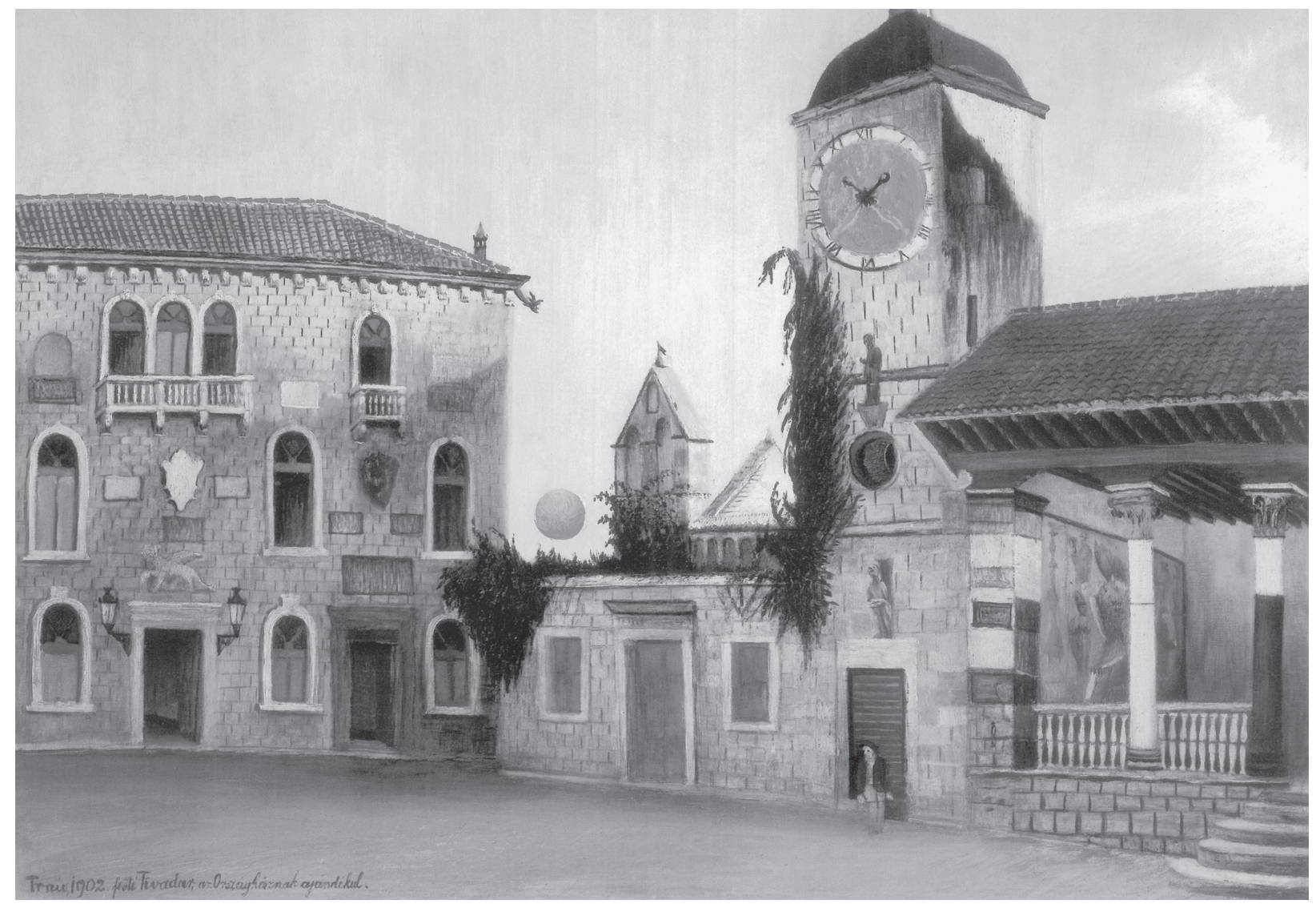

23. Csontváry Kosztka Tivadar: Visszatekintő nap Trauban, 1902. Budapest, Dr. Szegedy-Maszák Mihály tulajdona

lóban nem törekedett újszerű vagy éppen szokatlan témák felkutatására. Sőt, az embernek az az érzése, hogy kifejezetten kereste a korban jól ismert populáris és így könnyen felismerhető témákat, tájelemeket.

A konvencionális témák, motívumok mellett triviálisak a képek konkrét beállításai is. Nem is csoda, hogy a közelmúlt kutatásai képeslapokra és egyéb, a korszakban népszerü felvételekre vezetik vissza a festő korai tájképeinek kompozícióit. ${ }^{50}$ Sőt, annak a lehetősége is felmerült, hogy a művész kizárólag fotográfiák használatával készítette festményeit anélkül, hogy az adott helyszínt felkereste volna. ${ }^{51}$ Galavics Géza arra is felhívta a figyelmet, hogy előképeit nem csupán a korabeli képeslapok és divatos újságok illusztrációi közül válogathatta Csontváry, hanem az Uránia Magyar Tudományos Színház népszerű előadásain felhasznált gazdag mozgókép- és fotóanyag is inspirálta öt. Szinte bizonyos, hogy nemcsak a Vihar a Nagy Hortobágyon (1903) címü alkotás előképeit, hanem a festő bosznia-hercegovinai utazásának ötletét is egy ilyen ismeretterjesztő előadás adhatta. ${ }^{52}$ Minden jel arra utal, hogy Csontváry elfogadta és követte a kor fotográfusainak sokszor már több évtizede alkalmazott beállításait, kliséit. A fotó kizáró- lagos alkalmazásának teóriája azonban több szempontból sem állja meg a helyét. A fentebb ismertetett "munkamódszer" ennek eleve ellentmond, de a helyszínek és a festmények alaposabb összevetése még több bizonyítékot szolgáltat erre.

Csontváry tájképeinek helyszíneit tanulmányozva szembetúnő, hogy a festő a legnagyobb alapossággal rögzítette témáit, motívumait. A festményeken látható motívumok többsége ma is pontosan azonosítható. E tény ellenőrzését sokban megkönnyíti, hogy a festő nem használta a levegőperspektívát. ${ }^{53}$ Ezért a festmények hátterében megbúvó részleteket ugyanaz a gazdag mesélökedv jellemzi, mint az előtér motívumait. Ellenben nem mondható el ez a korabeli képeslapokról: a tengerpart párás légköri viszonyai között készült felvételek „életlensége” miatt e képeslapok legtöbbször adósak maradnak a részletgazdagsággal. A castellammarei keleti tájolású két képen látható tengerparti paloták részletei - eltekintve a későbbi átépítésektől - tökéletesen megegyeznek a mai valósággal. Az épületek tagolása - az emeletek és a tengelyek száma, a homlokzatok jellegzetes részletei - teljesen azonos. A látványt a legapróbb részletekig követő munkamódszer nemcsak az előtér, 
hanem a háttér esetében is tökéletesen érvényre jut. A hegyoldalon álló épületek, mint például a ferences rendi kolostor vagy a hajógyár épülete, valamint a római kori fürdő mellett álló centrális kegytemplom - szemben Csontváry valósághű részleteivel - a képeslapokon alig kivehetők. A taorminai festmények közül szempontunkból a Piazza Sant Agostino a legbeszédesebb. Csontváry festményén a tér sarkán álló óratorony mögött lévő épület homlokzatán egy kapu és egy erkély motívuma látható. E két homlokzattagoló elem egyetlen, a korból fennmaradt - és általam ismert - fotográfián sem látható jól, mivel az adott részleteket a környező épületek árnyéka eltakarja, gátat szabva ezzel a festményhez hasonló részletességnek. Ugyanez a helyzet a már említett $A$ taorminai görög színház romjai (1904-1905) jobb oldali árkádívével, ahol a háttérben meghúzódó Giardino Villa Comunale részletei egyetlen ismert korabeli fotón sem vehetők ki jól. Csontváry viszont az árkád ivében felbukkanó fák jellegét is tökéletesen megfigyelte (2. kép).

Hasonló következtetésekre juthatunk, ha nem a valóság, hanem a festmények felől közelítünk a látvány és a kép viszonyához. Csontváry középtengelyes kompozícióin rendszerint egy hangsúlyos motívumot helyez el a kép függőleges középvonalán. Jellemző, hogy ezeknek a motívumoknak a kép többi részletével tartott viszonya (elhelyezkedés, arányok) rendre egyezik a valósággal. A taorminai görög színház első változatán, a Kis Taorminán (1903) a középtengelyen a háttérben egy kolostor áll. Ha a valóságban megkeressük a kép rögzítésének pontos helyszínét, az erről a pontról készített fotófelvételen ugyanoda, azaz a fotó függőleges középvonalára kerül az épület. A kolostornak az őt körülvevő részletekkel tartott viszonya pedig ugyanazt az összhatást mutatja, mint ami a festményen is megfigyelhető (24. kép).

A Visszatekintő nap Trauban (1902) címü képen ugyanez a precizitás figyelhető meg. Ez esetben a kép középtengelye a városháza és az óratorony között, a kissé hátrébb álló harangtoronnyal esik egybe. Csontváry itt sem kompilál: megkeresi a téren azt a pozíciót, ahonnét a harangtorony épp a festmény középtengelyére kerül. Az épületek helyzetéből ez kikövetkeztethető. Látószögéből ezért kerül ki például a kép jobb oldalán álló, a korabeli képeslapokon rendre felbukkanó római kori portikusz nagy része. Míg a képeslapok a látnivalók tárházát próbálják a szemünk elé varázsolni, Csontváry elsősorban a háttérben álló toronyra és az épületek között kibukkanó égboltra koncentrál. Ezek az alapos és körültekintő beállások arra engednek következtetni, hogy a festő valóban a helyszínen kereste

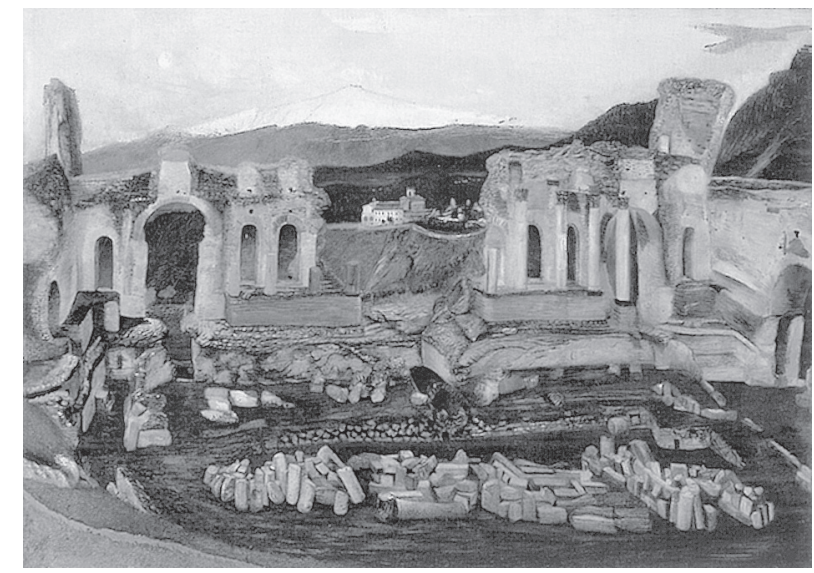

24. Csontváry Kosztka Tivadar: Kis Taormina, 1903. Budapest, Magyar Nemzeti Galéria, ltsz.: 6718. Pécs, Csontváry Múzeum, letét

meg a számára megfelelő pozíciót, nem pedig a korabeli fotók motívumait vagy a helyszínen végzett részlettanulmányokat kompilálva állította össze képei kompozícióit.

Meg kell jegyeznünk, hogy Csontváry festményein néhány esetben találunk a valóságot átíró részleteket. Inkább egyfajta torzítás ez, semmint a látvány átrendezése vagy felülírása. Csontváry kizárólag olyan változtatásokat eszközöl, melyekkel kompozicionális alapsémákhoz tudja igazítani a látványt. Célja a kép összhatásának kiegyensúlyozottabbá vagy éppen mozgalmasabbá tétele. Két alapvető komponálási séma jellemző a vizsgált időszakban készült tájképeire. Az első típus egy horizontális szerkesztési mód, amelyen a kép alapsíkjával párhuzamosan, színpadszerü beállításban ábrázolja az elénk táruló látványt. Ilyen például Selmecbánya (1902), a Tavasznyílás Mosztárban (1903) vagy éppen a taorminai görög színházat ábrázoló két kép is.

A második séma egy diagonális szerkesztési mód. Ez bukkan fel a trogiri, a castellammarei, a korai taorminai, valamint a mosztári római hidat ábrázoló képeken (1903). Ez utóbbi kompozíciótípus esetében a kép középterébe vezetô út, híd, mellvéd motívumainak szerepe kiemelten fontos. E részletek markáns, a valóságnál lényegesen „feszesebb" ábrázolásához sokszor a valóság felülírására kényszerül a festő. Ez történik például a castellammarei három festmény esetében, ahol a tengerpart homokpadozata „esik áldozatul” a merészebb komponálási megoldásnak: Csontváry mindhárom ott készült festményéről elhagyja a föveny motívumát.

$\mathrm{Az}$ általam érintett helyszíneket Csontváry alaposan tanulmányozta. A képeken látható részletek olyan fokú helyismeretre vallanak, amelyek min- 
den kételyt eloszlatnak afelől, hogy a festő esetleg nem a helyszínen készített tanulmányok alapján festette volna azokat. A fentebb elemzett következetes tájolási gyakorlat és a valóságot követő komponálási megoldások lényegében kizárják a fotók alapján festett tájképek teóriáját.
Mi célt szolgáltak akkor e festmények készülte során a képeslapok? E kérdés megválaszolásához elég, ha újra felelevenítjük a festő 1903-ban Haranghy Györgyhöz írott első levelét, s az abban rejlő tanulságokat kiegészítjük a fenti megfigyelések részleteivel.

„Igen tisztelt Uram!

Budapesten, az Uránia színházban arról értesülék, hogy Ön rendkívüli szakértelemmel a Hortobágyi pusztáról felvételeket bámulatra méltó módon készít.

Én ezt nem az apparátusnak tulajdonítom, épezért fordulok Önhöz, volna kegyes engem felvilágosítani a következőkről:

Mi a fömotívum a H. pusztán? az ég, a naplemente- vagy kelte? az égen a viharos felhőzet vagy a puszta föld?

Mi adja meg a hangulatot? a távolban lévő állati foltok, vagy a közelben levők? bikák, lovak vagy száguldó csikósok?

Van-e ott helyiség egy kb. 150-100 centiméter arányú vászon megfestésére? mely idő a legalkalmasabb egy hű kép megfestésére?

Végül egy hónapi tartózkodás a pusztában lehetséges-e? nem kell-e a polgármester ajánlása stb.

Ez k. b. az amire előre óhajtanék egy kis tájékozást szerezni, az Ön szívessége

által, ha nem terhelem meg a kérésemmel, az esetben kegyeskedjék engem értesíteni.

Jelenleg Jajce vízesését festem s néhány nap múlva befejezem; innen valószínű e hó 20.ka után elutazom, valószínű Szigetvárra; s ha ott meglelém a mit kívánok találni, ott festek legalább egy hónapig; azután Hortobágyi pusztát tekintem festői motívnak.

Ha igen tisztelt uram szükségesnek találja azt, hogy felvételei által reám jó benyomást gyakoroljon a puszta, szívesen viselem a pósta költséget ide-oda-: de ha célszerübbnek vélné azt, zárt szemmel a helyszínén megjelenni s egy eredeti hangulatot bemutatni, úgy én bátorkodnám Debrecenben felkeresni.

Ezek után vagyok igaz tisztelettel

Jajce 1903 június 4

(Bosznia)

Kosztka Tivadar

festőmüvész" ${ }^{54}$

A Haranghyhoz írt levélben Csontváry a Vihar a Nagy Hortobágyon címú képéhez kért útmutatást a fotográfustól. A levél már számtalan cikkben, tanulmányban állt az elemző kutatás középpontjában. Anélkül, hogy a korábbi kutatás eredményeit felsorolnám, pusztán azokra a részletekre kívánok kitérni, melyek az általam érintett részletek szempontjából lényegesek.

Csontváry képei és a modellként szolgáló táj közötti viszony feltárása azt bizonyítja, hogy a festő fotókból inspirálódott, és maga is azokhoz hasonló beállításokat alkalmazott. A festés múvelete során azonban kétségtelenül a természetre hagyatkozott. A levélben feltett kérdések így véleményem szerint csak arra vonatkozhatnak, hogy a festő az adott motívumot a legtalálóbb beállításból és a legjellemzőbb fényviszonyok mellett kívánta rögzíteni. Lényegében mindegy volt számára, hogy az útmutatás fotók formájában történik meg vagy személyesen: „ha célszerübbnek vélné azt, zárt szemmel a helyszínén megjelenni s egy eredeti hangulatot bemutatni, úgy én bátorkodnám Debrecenben felkeresni...". A lényeg az, hogy a festő a legjellemzőbb beállítást találja meg. A legjellemzőbb alatt pedig itt az évtizedek során közismertté, közkinccsé vált, általánosan elterjedt beállításokat értem. A vidéket fotósként (képkészítőként) ismerő Haranghynál pedig keresve sem találhatott volna jobb vezetőt erre. 
Csontváry kérdéseiből és munkamódszeréből arra következtethetünk, hogy a festő eleve vizuális toposzként vagy konvencióként kezelte az adott képtémákat. Azoknak viszont csak rögzült, szimbolikus formáit - ilyen például egy jellemző beállítás használta fel az alkotás során. A téma konkrét rögzítésekor ugyanakkor lényegesnek tartotta a személyes jelenlétet, tanulmányok készítését, s megkockáztatom: a helyszínen történő festést is. ${ }^{55}$ Mindezt azért, hogy saját invenciói alapján a szimbólumban rejlö, számára fontos tartalmat a saját festői eszközeivel tegye láthatóvá. Legyen az akár egy bibliai történet, egy jellemző magatartásminta vagy historikus helyszín, azt a maga sajátos, plein air-tanulmányain kiérlelt festői technikájával akarja kibontani. Valóban nem a látomás született meg először a fejében, ahogy azt Kampis Antal ${ }^{56}$ vagy eleinte Németh Lajos ${ }^{57}$ gondolta. Jászainak ${ }^{58}$ és Galavicsnak ${ }^{59}$ volt igaza, akik szerint Csontváry kész képi és kulturális toposzokból indult ki a munka során.

A kérdés ebben a diskurzusban inkább az, hogy Csontváry vajon miért nem lázadt a kor vizuális konvenciói ellen, miért nem zavarták képeinek a képeslapokkal azonos beállításai? Miért nem a speciális, szokatlan, merész nézeteket kereste, ahogy a kor haladó szemléletű művészei, alkotócsoportjai a századfordulón?

Régóta tudjuk, hogy a triviális, konvencionális vagy a populáris toposzokhoz, a hagyományokhoz való ragaszkodás nem csak a festészeti gyakorlat szempontjából alapvető eleme Csontváry müvészetének. Sinkó Katalin Csontváry elhivatástörténetének és a 19. századi Raffaello-kultusz részleteinek hasonló vonásait elemezve mutatott rá, hogy a festő saját missziójának gyökerei a század közepének nazarénus mozgalmáig vezethetők viszsza. Csontváry saját elhivatástörténete ugyanabból a kulturális közegből, múvészettörténeti hagyományból ered, mint a plein air-tanulmányok választott helyszínei. Az elhivatásmítosz (Raffaellokultusz), festészetének jellemző műfajai (vallásos történelmi festészet, portré, tájkép), a témaválasztás (Uránia), valamint a képi toposzokon (képeslapok) keresztül a festészeti gyakorlata is ugyanahhoz a 19. századi hagyományhoz kapcsolódik.

Csontváry ilyen értelemben nem volt forradalmi alkat. Feltehetô, inkább természetesnek tartotta a romantikából eredő, sokszor már közhelyszerünek számító mintákat. Egyáltalán nem zavarta a festészeti tradíció és a populáris kultúra. A 19. század művészetét sem elvetni, sem „autentikusabb" utak keresésével túlszárnyalni nem akarta. Inkább a hagyományok életben tartásával törekedett az akadémizmussal kiüresedő vallásos, történelmi festészet megújítására. Erre utal Sinkó Katalin is, amikor
Csontvárynak a múlthoz és a jelenhez való viszonyáról ír: „...Csontváry a múlt és a jelen közötti kontinuitást vagy inkább azonosságot érzékelteti, ellentétben historizáló kortársaival, akik számára a múlt: exemplum csupán. ... Csontváry eredetiségének titka épp abban rejlik, hogy úgy alkotott, mint aki nem sejti, a régmúlt értékviszonyai véglegesen érvényüket vesztették." ${ }^{\prime 60}$

Bár Csontváry ismerte a realizmus és a plein air modern irányzatait, ezekre a friss áramlatokra sem úgy tekintett, mint a klasszikus festészettel szakító tendenciákra. A plein air esztétikáját egyáltalán nem osztotta, gyakorlatát pedig már-már természettudományos alapossággal, laboratóriumi precizitással, csak egyénien értelmezve alkalmazta. Mint láttuk, a plein air gyakorlatát saját kozmológiájának megfelelően átalakította, hogy a belőle létrehozott napút-festészettel túllépjen a valóság „spontán”, „egyszerü" ábrázolásán. Felülírta a valóságot, de nem a szelektálás elvét használta, miként a 19. század szinte valamennyi új irányzata. Ô a bővítés eszközével élt. Bővítette a távlatot, bővítette az idődimenziót, történelmi perspektívát alkalmazott, intuitív módon kidolgozta a több fényforrás gyakorlatát, majd később a több nézőpont alkalmazását is - mint például a Baalbeken. Mind történelmi, mind fizikai vonatkozásaiban kibővítette az egyszerü látvány vonatkozási rendszerét. Nem új formát keresett, hanem a meglévő sablonok bővítésével próbálta mitizálni képei világát.

Nem véletlen, hogy Perneczky Géza a 19. század hagyományos mintáit, toposzait sajátosan értelmező és bővítő Csontváryt ahhoz a Mahlerhez hasonlítja, aki a festővel megegyező technikával dolgozott: "Csontváry hermetizmusa éppen abból adódott, hogy ilyen sablonokkal dolgozott, és hogy e sablonok maguktól kínálták a távolságtartás taktikáját. És nyilvánvaló, hogy végső helyét is csak akkor tudnánk megtalálni, ha összevetnénk őt a hagyományos formák nagy kiürítőivel, a sablonok átszellemítőivel, a misztika és a konkrét ábrázolás kettősségének a korszakban fellépő képviselőivel. Egy muzsikus neve, Mahleré jut először az eszembe, aki ugyanezekben az években - véletlenül? - szintén Budapesten töltött néhány évet, mint az Operaház vezetô karnagya. Csontváryra hasonlít a természetimádata és az is, hogy ezt, bár mitizálta, mégis a kávéházak közhelyeinek a nyelvén mondta el. Míg a hegyekben sétált, meghatottságát sramlizenével stilizálta (Csontváry »polgári« munkái, mint a Sétakocsikázás, a háború alatt elveszett Kairói est vagy a Sétalovaglás is tulajdonképpen Hölderlin közelébe hozott »sramliképek «)." ${ }^{\prime 61}$

Bár a „kávéházi közhelyek” és a „sramlikép” hasonlata kicsit erös, Perneczky megállapításai alap- 
vetően találóak Csontváry sablonokból építkező művészi gyakorlatának jellemzésére. A kiüresedő 19. századi formák és a misztikus elragadtatottságra hajlamos világlátás különleges eredményt hozott létre a Csontváry-életműben. Ez a kettősség azonban már születésekor magában hordozta a szubjektivizmus útvesztőit, és így a közönség érdektelenségét, a meg nem értettség csíráját. A festészet igazságának új formáit ekkor már egy egészen más úton járva keresték a progresszív irányzatok képviselői.

1903-ra a tanulmányok és kísérletezések első fázisa lezárult Csontváry festészetében. A művész arzenálja ekkor már majdnem teljes. Kiérlelt szimultán technikájával képein a tér és az idő lehatároltsága megszünik, végtelenné tágul mindkettő. A köznapi tapasztalat és a tudomány számításai ekkor már jelentéktelenné, valótlansággá törpülnek képein. Ez a technika legtökéletesebben a Baalbeken érvényesül majd, ahol poétikusan kezelte az axonometrikus, a lineáris és a naiv perspektivikus megoldásokat. De addig még hátravan kísérletezéseinek második fázisa: a boszniai kirándulás, a nagy vízesések megfestése, kairói utazása és a görögországi tanulmányút.

Csontváry 1905-ben festi meg a Taorminai görög színház romjait. Az európai kultúra legdélebbi pontján, ott, ahol Taormina szikláin túl a semmibe vész a tekintet. A képzelet a túlparton Afrikát sejti, Egyiptomot, ahova a festőnek még el kell jutnia, hogy megtanulja a „világító” színek használatának receptjét. Hogy végre elmondhassa, és világgá kiálthassa: „Pleinair erfunden ...”. Hogy visszatérve Taorminába, megfestve a görög színházat, immár győztesként hagyja el Európa antik-középkori kultúráját a legendák földjéért, a Közel-Keletért.

\section{JEGYZETEK}

1 A Csontváry-szakirodalmat körülvevő tárgyi tévedések és a további félreértések elkerülése végett a festmények címét és datálását Romváry Ferenc: Csontváry Kosztka Tivadar 1853-1919 (Alexandra Kiadó, Pécs 1999) című œuvre-jegyzéke alapján adtam meg a tanulmányban. A szövegben pontosan jelzem, ha a Romváry által közölt adatok helytelenek.

2 Csak a legfrissebb irodalmat tekintve is számtalan új kérdést fogalmaz meg a kutatás. Lásd például: Tímár Arpád: Megjegyzések néhány Csontváry festmény címváltozatához. Jelenkor LVII. 2014/4, 433-441; Losonczy István: Színút - A színkompozíció párhuzamai Csontváry Kosztka Tivadar és a Nyolcak festészetében. Artmagazin 10. 2012: 3, 20-25; Molnos Péter: Csontváry. Legendák fogságában. Népszabadság Könyvek, Budapest 2009, 52-55; Galavics Géza: Csontváry, a Hortobágy és a fotográfus (Haranghy György emlékezete). Ars Hungarica XXIII. 2005/1, 55-88.

3 A modellként szolgáló táj és a megfestett kép közötti viszony vizsgálatát az alábbi festmények esetében végeztem el: Pompeji Have, 1897-1898, œuvre-jegyzék: 39.; Pompeji Porta, 1897-1898, œuvre-jegyzék: 40.; Viszatekintó nap Trauban, 1899, œuvre-jegyzék: 42.; Éjszaka Trauban, 1900, œuvre-jegyzék: 43.; Holdvilágos éj Trauban, 1899, œuvre-jegyzék: 44.; Délelótti kis plein air Trauban, 1900, œuvre-jegyzék: 45.; Délutáni vihar Trauban, 1900, œuvrejegyzék: 46.; Olasz város, 1901, œuvre-jegyzék: 50.; Villa Pompeji, 1901, œuvre-jegyzék: 51.; Mandulavirágzás, 1901 körül, œuvre-jegyzék: 52.; Füstölgó Etna, 1901 körül, œuvre-jegyzék: 53.; Olasz halász, 1901 körül, œuvrejegyzék: 54.; Holdtölte Taorminában, 1901, œuvre-jegyzék: 55.; Mandulavirágzás Taorminában, 1902, œuvre-jegyzék: 56.; Esti halászat Castellammaréban, 1901, œuvre-jegyzék: 59.; Világitó éj Castellammaréban, 1901, œuvre-jegyzék: 60.; Castellammare di Stabia, 1902, œuvre-jegyzék: 61.; Tengerparti város, 1902 körül, œuvre-jegyzék: 63.; Tavasznyilás Mosztárban, 1903, œuvre-jegyzék: 68.; Római híd Mosztárban, 1903, œuvre-jegyzék: 69.; Egy est Kairóban, 1904, œuvre-jegyzék: 94.; Kis Taormina, 1904, œuvrejegyzék: 102.; A taorminai görög színház romjai, 1904-1905, œuvre-jegyzék: 103.

$4, \ldots .$. úgy hogy nekem sem maradt egyéb hátra, mint az Akadémiától elbúcsúzni s a szabad természetben keresni a motívumot további fejlődésre nézve." Lásd: Csontváry kiadatlan önéletrajza. In: Németh Lajos szerk.: Csontváry-emlékkönyv. Corvina, Budapest 1976, 86. (4. j.)

5 Lásd Csontváry saját kiadású katalógusainak mútárgylistáit, amelyek időrendben a következők: Exposition Csontváry-Kostka. Grande Serre de la ville de Paris, Cours la Reine, Paris, 1907. Du 7 juin au 7 juillet; Csontváry képkiállítása. Városligeti Iparcsarnok, Budapest, 1908. november; Katalog der Bildergalerie von Th. V. Csontváry-Kosztka (Tschont-waari-kost-ka) Kunstmaler. Berlin, 1910; Csontváry Kosztka Tivadar képkiállítása Budapesten. Régi József Műegyetem Budapest, Múzeum körút 6-8., 1910.

6 A taorminai görög színház romjai, 1904-1905 (œuvrejegyzék: 103.) kivételével az általam vizsgált összes kép vagy a Kosztka család tagjaitól, vagy Kecskeméten keresztül a gácsi patikából kerültek elő az 1920-as és az 1930-as években. Egyik sem volt ott a budapesti műteremből Gerlóczy által 1919-ben megmentett darabok között.

7 Kaszás Gábor: Csontváry Kosztka Tivadar - Traui tájkép naplemente idején, 1899. Virág Judit Galéria, Budapest 2012, 24.

8 Lehel Ferenc például „asszociációs hibának” tartja az eltérő színezést és a hegyvonulat rajzának megszakadását: „Például, amint a taorminai színházromok egy nyílásán keresztül kilátni a vulkán lábára, mely aztán a romok felett nyúlik égnek, a hegyláb vonalai nem esnek össze a tető vonalaival, minthogy a festô nem nézte őket együtt és csakugyan a kétfélekép felfogott levegöperspektíva következtében a felsőrész színezése is más, mint az alsórészé." L. Lehel Ferenc: Csontváry Tivadar. 
A posztimpresszionizmus magyar előfutára. II. vázlat. Les Editions De Style, Paris 1931, 26.

9 Csontváry az alábbi módon határozza meg A taorminai görög színház romjai címü képének témáját: „Görög színház az Etnával és 250 méter mélyen a tengerrel - naplementén." L. Mezei Ottó szerk.: Csontváry-dokumentumok I. Új Müvészet Kiadó, Budapest é. n. 46.

10 Németh Lajos: Baalbek. Képzőművészeti Alap, Budapest 1980, 82.

11 Mezei Ottó: Az élő perspektíva. Müvészet XX. 1979/1,10-14.

12 Megjegyzendő, hogy Csontváry jó baráti viszonyt ápolt azzal a Feszty Árpáddal, aki A magyarok bejövetelén hasonló problémákkal szembesült 1894-ben. „Fesztyt különösen érdekelték Csontváry monumentális, nagyméretü festményei, mert $A$ magyarok bejövetelén saját magának is hasonló feladattal kellett megküzdenie." Feszty Masa festőművésznő közlése. Lásd: Csontváry-emlékkönyv, i. m. (4. j.) 137. A két festő személyes kapcsolatáról 1. még: Feszty Masa - Ijjas Antal: Feszty Árpád élete és müvészete. Jel Kiadó, Budapest 1999, 134-135.

A Feszty-féle körpanoráma lényegében ugyanahhoz a műfaji kérdéshez kötődik, amivel Csontváry kísérletezik saját korai képein. A festmény behatárolt, kimetszett látványának kiterjesztéséről van szó, amit a képsík kétdimenziós voltának átértelmezésével igyekezett leküzdeni mindkét müvész. Feszty a jól ismert panorámakép müfaján belül a végtelenné tett képsíkkal, azaz a 360 fokban kiterjesztett látvánnyal lépi át a két dimenzió korlátait. Csontváry elsősorban életképein alkalmaz ilyen "gömbperspektivikus" megoldásokat. Tájképei esetében, mint látni fogjuk, őt is elsősorban a panorámafestészet hagyományai inspirálták.

13 Mezei szerk. i. m. (9. j.) 80.

14 Lásd például Romváry megjegyzéseit a taorminai képekkel kapcsolatosan: Romváry i. m. 1999 (1. j.), œuvrejegyzék: 56.

15 E munkát Virág Judit, Törő István, valamint e szöveg írója végezte el. L. Kaszás i. m. (7. j.) 2012.

16 Itt kell megjegyezni, hogy a képpárok összetartozó darabjaihoz szinte kivétel nélkül eltérő évszámok kapcsolódnak. Csontváry saját kiadású katalógusaiban kettős évszámokkal látta el a trogiri (1899-1900), a castellammarei (1901-1902) és a taorminai (1901-1902, 1902-1903) képpárokat is, dacára annak, hogy e művek keletkezési helye és körülményei épp az egyidejüséget feltételeznék. Az eltérő datálás oka az lehet, hogy télen, azaz a naptári évforduló környékén készültek ezek a festmények. Erről lásd a festő „Egy idő óta fővárosunk levegőjét nem bírom szívni betegség nélkül..." kezdetü levelét K. Lippich Elekhez. Országos Széchényi Könyvtár Kézirattár, Levelestár. Közli: Csontváry-emlékkönyv i. m. (4. j.) 52-54, valamint Mezei szerk. i. m. (9. j.) 74. Az sem zárható ki, hogy Csontváry később maga „választotta szét" az összetartozó darabokat. Katalógusaiból kitünik, hogy a képpárok tagjai - ha egyáltalán mindkettőt kiállította az adott tárlaton - rendre egymástól külön szerepeltek a mütárgylistában. Egyetlen kivétel a párizsi brosúra, ahol a múvész egy csoportba szedve sorolta fel a négy trogiri képet, illetve két castellammarei darabot: Exposition... i. m. 1907 (4. j.) kat. 11-14. és 17-18.

17 A három tájkép mellett Castellammarében készült az Öreg halász (1902 körül). A város topográfiai vizsgála- tából igazolható az is, hogy e négy képhez még egy további alkotás tartozik: ez a festmény az Egy este Kairóban (1904). A korábban Neményi Bertalan gyưjteményéből feltehetőleg Oroszországba hurcolt kép helyszíne megegyezik Castellammare főterével, a Piazza Principével. A korábbi kutatás téves helyszín-attribúciójának lehetőségét már Molnos Péter felvetette: Molnos Péter: Kallódó kedvencek. http://kieselbach.hu/magazin/kepvadasz/ lappangok. Gyanúját az a tér közepén ma is látható pavilon táplálta, amelyre a 19. század végétől a halászváros közösségi életében központi szerep hárult. A Piazza Principét övezó épületek közül kettő ma is jól azonosítható. A kupola mögött balra látható, valamint a teret jobb oldalon lezáró épületek csak az azóta történt átépítések miatt nem felelnek meg tökéletesen a mai állapotnak. Bár a festmény ma csupán fekete-fehér reprodukcióról ismert, szembetűnő a pavilon sugárzó fénykupolája, amely nem a képzelet szüleménye. A pavilont üvegkupola fedi és fedte már a 20. század elején is. Ezt több korabeli képeslap is bizonyítja. A kupola szerkezetében ma is láthatók azok a reflektorok, amelyek által fényárban fürdik nemcsak a kupola palástja, de a környezó épületek és a pavilon alatt álló zenekar is.

18 Tanulmányomban később bizonyítom, hogy Csontváry Visszatekintő nap Trauban címü képe nem 1899-ben, hanem, ahogy azt a kép szignatúrája is jelöli, 1902-ben készült.

19 Csontváry életrajzából tudjuk, hogy első taorminai tartózkodása alkalmával Castellammaréból érkezik Szicíliába. Az útnak emléket állít egy kép is, amelyet korábban Tengerparti város, 1902 körül (Amalfi) címen tartott számon a kutatás. A festmény azonban nem a nápolyi öböl alatt található kisvárost, hanem sokkal délebbre, a félszigetet és Szicíliát összekötő kompállás, a Villa San Giovanni szomszédságában található Scillát ábrázolja. A kép készültének helyét Molnos Péter azonosította: Molnos i. m. 2009 (2. j.). 54.

20 L. Csontváry-emlékkönyv i. m. 1976 (4. j.) 87.

21 A festmény helyszínét ugyancsak Molnos Péter azonosította: Molnos i. m. 2009 (2. j.) 54.

22 Lehel i. m. 1931. (8. j.) 25.

23 A mű pontos helyszínét Árvai Mária Ország Lilikutatásai során azonosította. A hibás helymeghatározás forrása maga Csontváry lehetett, aki a meg nem valósult 1910-es berlini kiállítás katalógusában a következőképpen adja meg a címet: Have, das Haus des Chirurgen mit dem Vesuv. Ezt a hibát továbbgörgetve a festményt a Casa del Chirurgóval azonosította a szakirodalom, bár az sem elképzelhetetlen, hogy a festőnek a Casa del Chirurgót ábrázoló képe lappang. A Have elnevezés a ház bejárata előtti HAVE feliratú mozaikra utalhat, mely az AVE köszöntés régies változata.

24 Mezei szerk. é. n. (9. j.) 71.

25 A mozaikot 1843 szeptembere óta a nápolyi Museo Archeologico Nazionale ôrzi. A Casa del Faunóban ma látható másolat csak 2005-ben került elhelyezésre. Bár Csontváry sem az eredetit, sem a másolatot nem láthatta a helyszínen, minden bizonnyal tudott annak létéről és korábbi elhelyezkedéséről.

26 Csontvárynak az antik görög-római kultúra felett mondott ítéletével számtalan esetben találkozhatunk fennmaradt írásaiban. L. pl.: Mezei szerk. é. n. (9. j.) 87: „Az Isten büntetése utolérte a rómaiakat úgy Baalbekben 
mint Rómában ahol földrengéssel szórta széjjel Bacchusimádók munkáit és betemette vulkánnal Pompejiben a tivornya palotáit.”, vagy 124-125: „S mi ezektől az emberektől [a görögöktől és a rómaiaktól KG] tanultuk kétezer esztendeig a valótlanságokat irigységet fényüző pazarlást ivást telhetetlen élvezeteket akárcsak Pompejiben az elpusztult emberek."

27 A város történelmi jelentőségét tartja a helyszínválasztás elsődleges okának Romváry i. m. 1999 (1. j.) 60. Ezt valószínűsíti Németh Lajos is, bár a kérdésben nem foglal egyértelmű állást: Németh Lajos: Csontváry Kosztka Tivadar. Corvina, Budapest 1970, 230.

28 A kép jelzése a következő: „Trau 1902. festé Tivadar az Országháznak ajándékul”. L. Romváry i. m. 1999 (1. j.), œuvre-jegyzék: 42.

29 A Parlament épülete 1902-ben készült el. A festményt erre az alkalomra adományozhatta Csontváry az Országháznak. L. Németh i. m. $1970^{2}$ (27. j.) 30.

30 Uo.

31 A kép fényviszonyaira tett 2012-es megállapításaim tévesnek bizonyultak. Sem az óratornyon látható pontos idő (19:20), sem a nap megkettőződésének a gondolata nem helytálló. L. Kaszás i. m. 2012 (7. j.) 38. Azóta bebizonyosodott, hogy Csontváry e képek festése során végig ragaszkodott a látvány valósághű rögzítéséhez.

32 A napkeltére lásd: http://calendar.zoznam.sk/ sunset-hu.php?hy=1900\&latitude $=43.5089$ \&longitude $=1$ $6.4391 \&$ city $=3190261 \& z e n i t h=90.833333333333 \&$ timezon $\mathrm{e}=05 \mathrm{a} 1 \&$ submittype $=$ user\&firsttime $=$ no\& $\mathrm{x}=0 \& \mathrm{y}=0 \#$ July.

A hold állására: http://calendar.zoznam.sk/moonphasehu.php?hy $=1902 \& \mathrm{x}=0 \& \mathrm{y}=0$

33 Lehel i. m. 1931 (8. j.) 34.

34 Uo. 33-34.

$35 \mathrm{Ez}$ magyarázhatja, hogy Csontváry miért festette meg közel azonos beállításból kétszer ugyanazt a részletet. A két festmény szorosabb kapcsolatát bizonyítja az a tény is, hogy a párizsi kiállítás katalógusában párban szerepeltette azokat: Exposition Csontváry-Kostka i. m. 1907 (5. j.) kat.: 17-18.

36 A villát időközben lebontották, helyén ma egy hotel épülete áll.

37 Mezei szerk. é. n. (9. j.) 81.

38 Mezei szerk. é. n. (9. j.) 157.

39 Uo. 159.

40 Uo. 88 .

41 Lehel i. m. 1931 (8. j.) 15. Vö. Tímár Árpád: Forráskritikai problémák a Csontváry-kutatásban. Ars Hungarica XXVIII. 2000/1, 135-144.

42 Lehel i. m. 1931 (8. j.) 16.

43 Németh i. m. $1970^{2}$ (27. j.) 242.

44 Németh i. m. $1970^{2}$ (27. j.) œuvre-jegyzék: 48., illetve Romváry i. m.1999 (1. j.) œuvre-jegyzék: 42.

45 Csontváry-emlékkönyv i. m. 1976 (4. j.) 87.

46 Mezei szerk. é. n. (9. j.) 73.

47 Szabó Júlia: Csontváry Tivadar utazásai elődök és kortárs festők utazásai tükrében. Ars Hungarica XXI. 1993, 91-103.

48 Szabó Júlia: A mitikus és a történelmi táj. Balassi MTA Múvészettörténeti Kutató Intézet, Budapest 2000, 179.

49 Szabadi Judit: Csontváry Kosztka Tivadar helye korunk szellemi életében. A közelmúlt Csontváry-kutatásának rövid áttekintése. Holmi XXV. 2013/7, 901.
50 Molnos i. m. 2009 (2. j.) 52-55.

51 Molnos is utal erre, de a felvetés régebbi keletü, Haranghy Lászlótól ered. Ő őrizte 1956-ig azokat a leveleket, amelyek apja, Haranghy György amatör fotográfus és Csontváry kapcsolatáról árulkodtak a festő Vihar a Nagy Hortobágyon (1903) címú képének festése során. Az első levelet Kampis Antal facsimilében is közölte (Kampis Antal: Csontváry ismeretlen levele. Müterem I. 1958. február, 4-6.), a többi sajnos elpusztult. Haranghy a legutolsó levélre később úgy emlékezett vissza, hogy abban a festő arról tájékoztatja a fotográfust, hogy „.... nem volt a Hortobágyon, mikor a hidat festette. Sőt, állítása szerint csak a fényképekre támaszkodva Haranghy írásbeli és képi irányításával festette meg a Vihar a Hortobágyon c. 1903-as képet saját felfogásában." Haranghy László közlését feljegyezte Vadász György: Délibábok hazája, avagy Haranghy György élete, munkássága a dokumentumok tükrében. Gépelt kézirat, Debrecen 1982, 1-92. Kecskemét, Magyar Fotográfiai Múzeum. A szöveget közli: Galavics i. m. 2005 (2. j.) 76. Az elgondolás nemcsak a müvek és a képeslapok beállításainak hasonlóságából ered. A felvetés másik sarkalatos pontja a nagyméretü tájképek problematikájához kapcsolódik: e darabok csak bajosan, számtalan nehézség árán kivitelezhetők a helyszínen.

52 Galavics i. m. 2005 (2. j.) 66.

53 A levegőperspektíva mellőzése összefüggésben állhat a Csontváry által sokat hangsúlyozott, de pontosan ki nem fejtett „élő távlat” kérdésével, amelynek hiányát olyan alkotókon is számon kérte, mint Leonardo vagy éppen Rubens. Lásd például: Mezei szerk. é. n. (9. j.) 80.

54 A levél szövegét a Galavics Géza által publikált verzióban közöltem, amely mind formai, mind tartalmi szempontból a Kampis-féle, facsimilében közreadott dokumentumot vette alapul. Lásd: Galavics i. m. 2005 (2. j.) 55-56.

55 A festmény és a modellértékű táj viszonyának általam elemzett sajátosságai mellett több részlet is alátámasztja ezt a feltevést. Véleményem szerint nem lehet Csontváry visszaemlékezéseit figyelmen kívül hagyni ebből a szempontból sem. Márpedig a festő számtalan esetben utal arra, hogy az adott motívumot a helyszínen festette meg. További bizonyíték a helyszínen történő munkára a fenti levélben szereplő kérdés: „Van-e ott helyiség...?", valamint a "Jelenleg Jajce vízesését festem..." kezdetü kijelentés. Nagyméretü képeinek kivitelezése során is találhatott arra alkalmas helyiséget. Tudjuk, a Nagy Tarpatak a Tátrában címú képét (1905) például Felkán hagyta száradni (Mezei szerk. é. n. [9. j.] 73.), és talán a Taorminai görög színház romjai is készülhetett a helyszínen. A színház nézőtere mögött egy dongaboltozatos folyosó fut körbe, amely alkalmas lehetett arra, hogy Csontváry a nagyméretü vásznat a festés és a száradás ideje alatt ott tárolja, s védje az időjárás viszontagságaitól.

56 Kampis i. m. 1958 (51. j.) 6.

57 Németh i. m. $1970^{2}$ (...) 75.

58 Jászai Géza: Csontváry kritikai jegyzetek. München $1965,27$.

59 Galavics i. m. 2005 (2. j.) 66.

60 Sinkó Katalin: A Madonna-festő. Müvész-szerep és historizálás Csontváry önarcképein. Müvészettörténeti Értesítő XL. 1991, 168.

61 Perneczky Géza: A rejtőzködő Csontváry. Holmi XV. 1993/3, 348. 


\section{ADDENDA TO CSONTVÁRY'S PLEIN AIR STUDIES (1897-1903)}

There is still much to be explored about the exact circumstances of the creation of Csontváry's pictures and the painter's working method. Research has either approached the œuvre from the life path wrought with mythical elements, or wished to embed it in the context of $19^{\text {th }}$ century painting tradition. From these angles, however, the consistently built visual logic of Csontváry's pictures, their details governed by the inherent laws of the genre of painting are often overlooked.

The most adequate method of exploring Csontváry's creative practice appears to be a thorough examination of the relation between the inspiring sight and the picture painted of it. I based this study on Csontváry's landscapes painted between 1897 and 1905, first of all those painted in Trogir, Castellammare and Taormina. In the knowledge of these localities it can be established that the painter accurately followed the topographic sight and the conditions of light. At the same time, the comparison of the location and the painting has also revealed that the painter had pairs of pictures in mind in his intention to capture a sight systematically. Taking up a vantage point mostly in northsouth and one in east-west orientation, he created "panorama pictures" built of several elements. His paintings are similar to the $360^{\circ}$ panoramas in photography. But while a rotating camera can take an infinite number of photos, the painter assembled the picture from two "shots".

Conspicuously, the pairs of pictures depict different times of day: instead of momentary impressions and moods, Csontváry captured the path of the transmission of light and thereby the passing of time, an interval of time in the pairs of pictures. In his later compositions he was to apply these different light conditions in a single picture, framing as it were the daily path of the planet on the horizon. This practice is related to one of Csontváry's key technical terms, the "Sun Path".

By capturing the changing of light in one picture Csontváry wished to "perfect" the $19^{\text {th }}$ century plein air technique. His "Sun Path" painting derives from a specific view of nature and the world, which was in polar opposition to the positivism of naturalism and the sensualism of impressionism. Proof of it is the pairs of pictures. They summarize all Csontváry's observations of time and space, and their translation into the practice of painting.

The views conveyed by Csontváry's paintings were often borrowed from contemporaneous picture postcards. Not only greeting cards but e.g. the rich moving picture and photo material of the programs of the Urania Hungarian Scientific Theatre inspired him. He treated the pictorial themes as visual tropes or conventions, but in the creative process he only used their fixed, symbolic form such as a typical cutting. When a theme was actually to be realized, he thought it indispensable to be on the site in person, to make sketches and paint on the spot. He did so to make the contents he found important in the symbol visible by his painting.

KASZÁS Gábor művészettörténész, Virág Judit Galéria, Budapest/art historian, Virág Judit Gallery Budapest

Kulcsszavak: Csontváry Kosztka Tivadar, plein air, napút, panoráma, képpár, fénytanulmány, fotóhasználat, vizuális toposz / Keywords: Tivadar Csontváry Kosztka, plein air,"Sun path", panoramic pictures, light study, photos, visual tropes 